
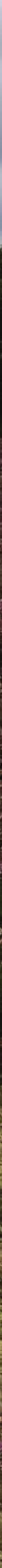

\title{
Beleidsadvies governance nationale parken
}

Internationale quickscan van standaarden en governance van nationale parken

Marcel Pleijte en Roel During 



\section{Beleidsadvies governance nationale parken}

Internationale quickscan van standaarden en governance van nationale parken

Marcel Pleijte en Roel During

Dit onderzoek is uitgevoerd door Wageningen Environmental Research (Alterra) in opdracht van en gefinancierd door het ministerie van Landbouw, Natuur en Voedselkwaliteit (voorheen het ministerie van Economische Zaken), in het kader van een Helpdeskvraag (KD-2017-054) die valt onder het Beleidsondersteunend onderzoekthema 'Natuur en samenleving' (projectnummer BO-11-021).

Wageningen Environmental Research

Wageningen, november 2017

Rapport 2851

ISSN 1566-7197 
Pleijte, M. en R. During, 2017. Beleidsadvies governance nationale parken; Internationale quickscan van standaarden en governance van nationale parken. Wageningen, Wageningen Environmental Research, Rapport 2851. 54 blz.; 4 fig.; 2 tab.; 25 ref.

In een internationale quickscan is nagegaan hoe de governance in een aantal landen en gebieden is georganiseerd bij het hanteren van een standaard voor Nationale Parken nieuwe stijl en het komen tot een sterk merk voor beschermde natuur- en landschapsgebieden. Geadviseerd wordt om voor de nieuwe standaard inspiratie op te doen bij de Green List van de IUCN, het Biodiversiteitsverdrag, de UNESCO-criteria en de sociale en economische impactervaringen van Rebanks bij werelderfgoedgebieden. Ook valt bij instelling van de Nationale Parken nieuwe stijl veel meer van de ruimtelijke strategieën en economische keuzemodellen uit het buitenland te leren en wordt ervoor gepleit om in ieder geval wettelijk vast te leggen dat overheden op verschillende schaalniveaus gezamenlijk de nationale parken gedeeltelijk financieren (basisfinanciering). Tot slot kunnen nationale parken - evenals in het buitenland - verschillende ambitieniveaus nastreven binnen een en dezelfde standaard, waarbij de governance complexer wordt bij een hoger ambitieniveau.

In an international quickscan, we examined how governance is organized in a number of countries and areas in the use of a standard and the emergence of a strong brand for protected nature and landscape areas. It is advisable to get inspiration for the new standard from the Green List of the IUCN, the Biodiversity Convention, the UNESCO criteria and the social and economic impact experiences of Rebanks at World Heritage sites. Moreover, when setting up the national parks new style, much more can be learned of the spatial strategies and economic choice models from abroad. At least can be legally established that governments at various board layers jointly partly finance the national parks (basic funding). Finally, national parks can, as well as abroad, pursue different levels of ambition within one and the same standard, with governance becoming more complex with a higher ambition.

Trefwoorden: beschermde gebieden, governance, Green List, IUCN, merkontwikkeling, nationale parken, ruimtelijke strategieën, standaard

Dit rapport is gratis te downloaden van https://doi.org/10.18174/428062 of op www.wur.nl/environmental-research (ga naar 'Wageningen Environmental Research' in de grijze balk onderaan). Wageningen Environmental Research verstrekt geen gedrukte exemplaren van rapporten.

2017 Wageningen Environmental Research (instituut binnen de rechtspersoon Stichting Wageningen Research), Postbus 47, 6700 AA Wageningen, T 03174807 00, E info.alterra@wur.nl, www.wur. nl/environmental-research. Wageningen Environmental Research is onderdeel van Wageningen University \& Research.

- Overname, verveelvoudiging of openbaarmaking van deze uitgave is toegestaan mits met duidelijke bronvermelding.

- Overname, verveelvoudiging of openbaarmaking is niet toegestaan voor commerciële doeleinden en/of geldelijk gewin.

- Overname, verveelvoudiging of openbaarmaking is niet toegestaan voor die gedeelten van deze uitgave waarvan duidelijk is dat de auteursrechten liggen bij derden en/of zijn voorbehouden.

Wageningen Environmental Research aanvaardt geen aansprakelijkheid voor eventuele schade voortvloeiend uit het gebruik van de resultaten van dit onderzoek of de toepassing van de adviezen.

Wageningen Environmental Research Rapport 2851 | ISSN 1566-7197

Foto omslag: Nationaal Park de Veluwezoom, gefotografeerd door Roel During. 


\section{Inhoud}

Woord vooraf $\quad 5$

$\begin{array}{ll}\text { Samenvatting } & 7\end{array}$

$1 \quad$ Gevraagd beleidsadvies $\quad 9$

$\begin{array}{lll}1.1 & \text { Opgave } & 9\end{array}$

1.2 Achtergrond 9

$\begin{array}{lll}1.3 & \text { Doelstelling en doelgroepen } & 10\end{array}$

$\begin{array}{lll}1.4 & \text { Vraagstelling } & 10\end{array}$

$\begin{array}{lll}1.5 & \text { Werkwijze } & 11\end{array}$

$\begin{array}{lll}1.6 & \text { Leeswijzer } & 11\end{array}$

Groeiende aandacht voor governance in de standaard voor nationale parken 13

$\begin{array}{lll}2.1 & \text { Inleiding } & 13\end{array}$

2.2 Inspiratie vanuit de IUCN: naar Green List en CBD 13

2.3 Inspiratie: UNESCO-criteria en sociale en economische impactervaringen $\quad 15$

$\begin{array}{lll}2.4 & \text { Conclusies } & 17\end{array}$

Observaties en inspiraties vanuit het nationale parkenbeleid in het buitenland19

3.1 Observaties na de quickscan

3.2 Ruimtelijke strategieën: zonering en het instellen van bufferzones rond Nationale Parken

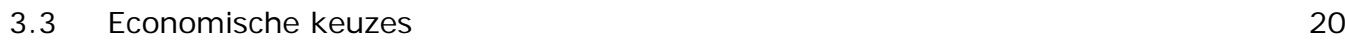

$\begin{array}{lll}3.4 & \text { Governance-modellen } & 22\end{array}$

$\begin{array}{lll}3.5 & \text { Governance en merkontwikkeling } & 25\end{array}$

3.6 Thema's en governance-arrangementen 26

$\begin{array}{lll}\text { 3.7 } & \text { Differentiatie in ambitie binnen de standaard } & 27\end{array}$

3.8 Terugkijkend naar Nederland vanuit de quickscan: wat valt op? 29

$\begin{array}{ll}\text { Literatuur } & 35\end{array}$

Bijlage 1 De standaard van de I UCN van beschermde gebieden 37

Bijlage 2 De standaard voor good governance van de I UCN 39

$\begin{array}{ll}\text { Bijlage } 3 & 41\end{array}$ 



\section{Woord vooraf}

Het Programma 'Naar Nationale Parken van Wereldklasse' heeft met de verkiezing van mooiste gebieden van Nederland en bijbehorende bidbooks op het schaalniveau van de afzonderlijke nationale parken al veel beweging en elan gecreëerd. Daarmee is niet alleen door het ministerie van Economische Zaken en de veertien andere samenwerkingspartners nagedacht over de te ontwikkelen standaard en merkontwikkeling, maar ook nadrukkelijk vanuit de Nationale Parken nieuwe stijl zelf. Hiermee wordt uitvoering gegeven aan de motie van Stientje van Veldhoven (D66) en Lutz Jacobi (PvdA) van drie jaar geleden. Dit heeft natuurlijk grote consequenties voor de governance, want er ontstaan nieuwe samenwerkingsverbanden die de sturingsvraag ingewikkelder maken tegen de achtergrond van een algemene achteruitgang van biodiversiteit in Nederland. Lokale trots, een duidelijke bijdrage aan de regionale of nationale identiteit vanuit de nationale parken kan heel heilzaam werken in het vinden van een natuurinclusieve regionale economie, maar de vraag is dan wel hoe dat zou moeten. Via deze quickscan zijn wij in de gelegenheid gesteld om na te gaan welke organisatievormen en organisatieprincipes elders gehanteerd worden om waardecreatie voor natuur, economie en sociale betrokkenheid mogelijk te maken. We laten zien dat als organisatiestructuren ingewikkelder worden, de noodzaak om deze zelf democratisch in te richten belangrijker wordt dan de noodzaak om democratische verantwoording af te leggen aan de verschillende bestuurslagen in het huis van Thorbecke. Interne democratie zal het dan moeten winnen van externe verantwoording. We hopen dat de voorbeelden in deze quickscan alle stake- en valueholders van de nationale parken zullen inspireren om een inclusieve en effectieve governance-structuur op poten te zetten die meerdere vormen van waardecreatie aanjaagt door middel van het stimuleren van alle actoren.

Marcel Pleijte en Roel During 


\section{Samenvatting}

Vanuit het Programma 'Naar Nationale Parken van Wereldklasse' wordt er een sterk merk met bijbehorende standaard voor Nationale Parken 'nieuwe stijl' ontwikkeld, waarbij aspirant-parken de mogelijkheid wordt geboden een aanvraag voor dit label in te dienen. Het ministerie van Landbouw, Natuur en Voedselkwaliteit (voorheen Economische Zaken) heeft Wageningen Environmental Research (WEnR, voorheen Alterra), onderdeel van Wageningen Universiteit en Research (WUR), gevraagd een beleidsadvies te geven door in een internationale quickscan na te gaan hoe de governance in een aantal landen en gebieden is georganiseerd bij het hanteren van een standaard en het komen tot een sterk merk voor beschermde natuur- en landschapsgebieden.

De auteurs van WEnR adviseren om voor de te ontwikkelen standaard zich te laten inspireren door de Green List van de International Union for Conservation of Nature (IUCN), het Biodiversiteitsverdrag (Convention on Biological Diversity (CBD), de UNESCO (United Nations Educational, Scientific and Cultural Organization) criteria en de sociale en economische impactervaringen van James Rebanks bij werelderfgoedgebieden.

Daarnaast adviseren de auteurs om bij de instelling van de Nationale Parken nieuwe stijl veel meer van de ruimtelijke strategieën en economische keuzemodellen uit het buitenland te leren en in ieder geval wettelijk vast te leggen dat overheden op verschillende schaalniveaus gezamenlijk de nationale parken gedeeltelijk financieren (basisfinanciering).

Op grond van de buitenlandse voorbeelden worden er vier ambitieniveaus onderscheiden, welke zouden kunnen passen binnen een en dezelfde standaard. De minimale ambitie bestaat uit behoud van biodiversiteit en educatie- en belevingsactiviteiten. Daarboven speelt de ambitie van een optimale wisselwerking tussen cultuur, cultuurhistorie, landschap en natuur. De één na hoogste ambitie kan worden gevonden in een nationaal park dat functioneert als aandrijvende kracht of economische motor van een regionaal sociaaleconomisch systeem. De hoogste ambitie kan bestaan uit een nationaal park als regionale strategie met een minimum aan transactiekosten en een maximale synergie tussen behoud en herstel van ecologische kwaliteiten en economisch functioneren.

Op basis van de quickscan wordt geadviseerd om voor de standaard Nationale Parken nieuwe stijl in wording verschillende vormen (maatwerk) van governance te ontwikkelen, afhankelijk van de relevante ruimtelijke strategieën en economische keuzes die kunnen worden gevolgd. Het lijkt zinvol om hier zo goed mogelijk aansluiting te zoeken bij Europese ontwikkelingen. Afhankelijk van het ambitieniveau dat wordt nagestreefd, kan hier meer of minder op worden ingezet. Hoe hoger het ambitieniveau, hoe complexer de governance wordt. Die ambitieniveaus kunnen echter verschillen binnen een en dezelfde standaard. 


\section{$1 \quad$ Gevraagd beleidsadvies}

\subsection{Opgave}

Buitenlandse voorbeelden van nationale parken en regionale natuurparken met een sterk merk worden veelal gekenmerkt door een combinatie van natuurlijke rijkdom, landschappelijke schoonheid en cultureel erfgoed (Pedroli et al. 2007). Als voorbeeld kan werelderfgoedgebied Fountains Abbey and Studley Royal Water Garden worden genoemd in het Verenigd Koninkrijk. Hier wordt deze combinatie aangetroffen met zeer hoge natuurkwaliteit (persoonlijke communicatie ex-trustee W. Jones, 21-6-2017). De site is in beheer van de National Trust, een organisatie met een lange governancetraditie. Hun motto luidt 'for ever, for everyone'. De governance bestaat uit een Board of Trustees, gevoed door een auditcommissie, een investeringscommissie en een senior management beloningsen vergoedingscommissie, evenals een Raad van Advies. Een van de interessante governancecomponenten is de zogenaamde whistleblowing policy. Alle betrokkenen in de governance, dus ook de vrijwilligers, hebben het recht om fouten in een besluitvormingsproces te signaleren en te agenderen. Als die niet informeel kunnen worden opgelost, dan komt het bij de voorzitter of een senior lid van de Trust te liggen, die daar actie op kan ondernemen. Zo kunnen eventuele scheve zaken worden rechtgezet, maar - veel belangrijker nog - zo draagt dit mechanisme bij aan een lerende governance.

Vanuit het Programma 'Naar Nationale Parken van Wereldklasse' dient er een sterk merk met bijbehorende standaard voor Nationale Parken nieuwe stijl te worden ontwikkeld, waarbij aspirantparken de mogelijkheid wordt geboden een aanvraag voor dit label in te dienen. Het Programma 'Naar Nationale Parken van Wereldklasse' (als toenmalig onderdeel van het ministerie van Economische Zaken) heeft WEnR gevraagd een beleidsadvies te geven door via een internationale quickscan na te gaan hoe de governance in een aantal andere landen en vergelijkbare gebieden is georganiseerd bij het hanteren van een standaard en het komen tot een sterk merk voor beschermde natuur- en landschapsgebieden. Het gaat hen om een snelle benchmark hoe de systeem- en stelselverantwoordelijkheid op overheidsniveau in deze landen is vormgegeven (macroniveau), hoe de samenwerking tussen de parken in verschillende landen is vormgegeven (mesoniveau) en hoe de organisatie van de governance op parkniveau eruitziet (microniveau). Wij hebben deze opdracht geïnterpreteerd als het zoeken naar de condities voor het bereiken van synergie tussen merkontwikkeling en herstel of behoud van biodiversiteit.

\subsection{Achtergrond}

Een van de opdrachten van het Programma Nationale Parken (PNP) is om tot een nieuwe standaard te komen voor nationale parken nieuwe stijl. Met de prijsvraag voor 'mooiste gebieden van Nederland' en de bijbehorende ingediende bidbooks in 2016 is voor nationale parken in Nederland een nieuwe werkelijkheid ontstaan. Die nieuwe werkelijkheid geeft houvast voor onze scope bij een quickscan om bouwstenen aan te leveren en dilemma's te benoemen voor een nieuw te ontwikkelen standaard. De nieuwe standaard dient volgens de opdrachtgever een set van criteria te omvatten die bestaat uit waarden vanuit bijvoorbeeld natuur en landschap, beleven, governance en financiering. De opgave is onder meer om de merkontwikkeling te combineren met een hoge standaard en daarbij te kijken wat de ervaringen hiermee zijn in het buitenland. Waarom aandacht voor governance bij het ontwikkelen van een standaard nieuwe stijl? Governance is onder meer nodig om ervoor te zorgen dat een sterke merkontwikkeling kan plaatsvinden, zonder dat je onder de ecologische minimumeisen van de standaard terechtkomt. Daarnaast zoekt het PNP op andere thema's verbinding vanuit governance. Het gaat dan om de bijdrage vanuit governance aan financiering, ruimtelijke inrichting en begrenzing, kwaliteitsbeleving, toegankelijkheid, beheer, communicatie, toerisme, educatie, voorlichting en onderzoek. Bij al die thema's speelt de vraag: hoe kunnen we dat qua governance goed regelen? Hoe is de governance op deze thema's in andere landen ingericht? 
Vanuit het PNP is het uitgangspunt hierbij 'structure follows strategy', ofwel: het blijft maatwerk qua governance wat passend is. Dit lijkt haaks te staan op het willen ontwikkelen van een standaard, want bij een standaard is eerder sprake van 'strategy follows structure', namelijk de structure van de standaard. De kunst is echter volgens PNP om een standaard te bieden die meerdere lonkende ontwikkelingsperspectieven biedt voor de parken, ofwel maatwerk. Het is daarmee een leer- en zoekproces om met de criteria om te gaan en hoe lonkende perspectieven daadwerkelijk gerealiseerd kunnen worden. Of bepaalde good governance criteria meer oppoppen qua prioriteit zal ook afhangen van de fases/ontwikkelstadia waarin een gebied verkeert. Volgens ons is het belangrijk om de governance zo in te richten dat ruimte wordt geboden voor het leer- en zoekproces.

In het Reglement voor de verkiezing 'Mooiste natuurgebied van Nederland', behorend bij het Programma 'Naar Nationale Parken van Wereldklasse (Staatscourant d.d. 2 mei 2016, nr. 2280), zijn al selectiecriteria gegeven die input kunnen leveren voor de standaard Nationale Parken nieuwe stijl:

- Het gaat om een samenhangend gebied waarbinnen natuurgebieden van (inter)nationale waarde zijn gelegen.

- Het gebied biedt unieke (potentiële) belevingsmogelijkheden, passend bij de draagkracht van het gebied.

- Draagvlak en samenwerking tussen partijen in het gebied zijn geborgd, er is voldoende organiserend vermogen en er zijn middelen om de samenwerking daadwerkelijk uit te voeren.

- Het gebied biedt kansen voor regionale sociaal economische ontwikkeling.

- Het gebied voorziet in adequaat bestuur/governance.

- Het gebied draagt bij aan de merkontwikkeling.

Voor de governance wil het PNP ook criteria opnemen in de standaard. PNP heeft eerder een opdracht uitgezet bij Stenden Hogeschool en European Tourism Futures Institute (ETFI) om een 'toolkit governance' te ontwikkelen. Het gaat daarbij dan vooral om good governance-criteria, zoals transparantie, betrokkenheid, participatie, zeggenschap, heldere besluitvorming, ambitie/visie etc. In deze quickscan zal worden nagegaan in hoeverre gebieden in het buitenland aan good governancecriteria refereren en welke governance-vormen verschillende landen hanteren.

\subsection{Doelstelling en doelgroepen}

Het doel van een internationale quickscan governance nationale parken is allereerst om bouwstenen te leveren voor de standaard Nationale Parken nieuwe stijl en bouwstenen voor een inclusieve governance-structuur. Daarnaast is het de bedoeling om nog andere bouwstenen aan te reiken voor het shareholdersoverleg van het Programma Nationale Parken. Op basis van de bouwstenennotitie kunnen de shareholders keuzes maken (of aanbevelingen meegeven) ten aanzien van 1) de invulling van de systeemverantwoordelijkheid van het Rijk en de provincies, 2) de inrichting van het stelsel rond de Nationale Parken en 3) over de inrichting van de onderlinge samenwerking. De doelgroepen zijn daarmee: 1) het expertteam Governance binnen het Programma naar Nationale Parken, 2) vervolgens het shareholdersoverleg van het Programma Nationale Parken en tot slot 3) de minister van LNV.

\section{$1.4 \quad$ Vraagstelling}

Het ministerie van LNV heeft behoefte aan een beleidsadvies. Hiertoe is de volgende centrale vraag geformuleerd:

Welk beleidsadvies is te geven na een quickscan en een SWOT-analyse van de opzet vangovernancestructuren in een aantal beschermde gebieden in het buitenland die vergelijkbaar zijn met de Nederlandse "bidbookgebieden" en die passen bij de ambities zoals geformuleerd in het Programma Naar Nationale Parken van Wereldklasse? 


\subsection{Werkwijze}

Begonnen is met een literatuurverkenning van standaarden, governance en merkontwikkeling voor beschermde gebieden. Daarbij is gebruikgemaakt van de zoeksystemen SCOPUS en Web of Science. De gevonden literatuur is tevens bestudeerd op de sociale en economische impact van beschermde gebieden.

Vervolgens hebben we een aantal gebieden in het buitenland bestudeerd die onder IUCN categorie II vallen of onder categorie IV of V. Daarbij lag de focus op governance-aspecten. Dit is gedaan middels de analyse van websites, jaarverslagen en andere online beschikbare bronnen. Gekozen is om de volgende landen te bestuderen: Duitsland, Engeland en Wales, Frankrijk, Italië, Spanje, Zweden en Zwitserland.

Bij deze analyse is gebruikgemaakt van de parate kennis en expert judgement van diverse collega's binnen en buiten Wageningen Environmental Research, die actief zijn in de (studie van de) internationale natuurbescherming ${ }^{1}$.

$\mathrm{Na}$ uitvoering van de internationale quickscan is vervolgens een SWOT-analyse van de governancemodellen in het buitenland gemaakt. Het gaat om een SWOT-analyse van de verschillende governance-modellen waarbij de landen gezamenlijk in beschouwing worden genomen en niet afzonderlijk (sterktes, zwaktes, kansen, bedreigingen).

Aanvullend heeft de analyse geresulteerd in een indeling van ambitieniveaus ten aanzien van merkontwikkeling met behoud en herstel van biodiversiteit, die werd aangetroffen in de internationale voorbeelden.

Vervolgens hebben we een aantal voorlopige algemene conclusies geformuleerd. Deze zijn op 3 juli 2017 gepresenteerd aan het Expertteam Governance van het Programma 'Nationale Parken van Wereldklasse'. Hun kritiek, vragen en suggesties zijn vervolgens verwerkt in deze eindrapportage. Tot slot is een aantal conclusies en aanbevelingen opgesteld ten aanzien van de Nederlandse situatie en de in het Programma Nationale Parken geformuleerde ambities. Er worden bouwstenen en dilemma's geformuleerd voor opname in een bouwstenennotitie ten behoeve van de op te stellen standaard voor Nationale Parken nieuwe stijl.

Het onderzoek heeft zich met name gericht op het verkennen van de synergie tussen biodiversiteit en merkontwikkeling, zoals beschreven in de opgave, en niet op de vraag wanneer een natuurgebied wel of niet in aanmerking zou moeten komen voor een nationaal park-label.

\subsection{Leeswijzer}

Dit rapport is als volgt opgebouwd. In hoofdstuk 2 wordt aangegeven hoe inspiratie kan worden ontleend aan de IUCN-criteria, het biodiversiteitverdrag, de UNESCO-criteria en de aandacht voor sociaaleconomische ontwikkelingen bij UNESCO-gebieden. In hoofdstuk 3 worden de observaties en inspiraties belicht vanuit het nationale parkenbeleid in het buitenland. Daarbij gaat de aandacht in het bijzonder uit naar overeenkomsten en verschillen in ruimtelijke strategieën en economische keuzes die wij herleiden tot vier verschillende governance-modellen. Hierna is aandacht voor governance in relatie tot merkontwikkeling, verschillende inhoudelijke thema's, differentiatie in ambitie binnen de standaard en wordt vervolgens vanuit de quickscan gereflecteerd op de Nederlandse situatie. Het rapport wordt afgesloten met een concluderend hoofdstuk, waarbij gekozen is om nogmaals kort de inspirerende praktijken te schetsen, dit op de Nederlandse situatie te betrekken en tot slot de lessen op te sommen die uitmonden in een advies.

\footnotetext{
${ }^{1} \mathrm{Er}$ is onder meer gebruikgemaakt van de kennis van Rob Glastra, van IUCN en van WUR-collega's Lawrence Jones-Walter, Irene Bouma, Mirjam Broekmeyer, Raoul Beunen.
} 


\section{Groeiende aandacht voor governance in de standaard voor nationale parken}

\section{$2.1 \quad$ Inleiding}

De criteria die zijn gehanteerd bij de verkiezing tot 'het Mooiste gebied van Nederland' kunnen in een standaard Nationale Parken nieuwe stijl worden gebruikt, waarbij onderscheid is te maken naar inhoudelijke criteria en naar de status van de nieuwe standaard (bijvoorbeeld een nieuwe gedragscode). Om een internationale quickscan te kunnen verrichten en de uitkomsten van de verschillende landen te kunnen duiden, is het van belang om te achterhalen welke standaarden andere lidstaten (kunnen) aanhalen.

\subsection{Inspiratie vanuit de IUCN: naar Green List en CBD}

De standaard voor beschermde gebieden, zoals nationale parken, verloopt grotendeels via IUCN en IUCNs World Commission for Protected Areas (WCPA). De WCPA heeft meer dan 2.500 leden uit 140 landen. WCPA werkt voor regeringen en anderen om beschermde gebieden te plannen en te integreren in alle sectoren door strategisch advies te verstrekken aan beleidsmakers en door capaciteit in beschermde gebieden te versterken. Bovendien is het aanhalen van de standaard van de IUCN voor beheerdoelen en governance-typen belangrijk, omdat die als mondiale standaard fungeert en als zodanig door de CBD (Conventie inzake Biologische Diversiteit, ook wel Biodiversiteitsverdrag genoemd) wordt erkend. Dit verdrag is het resultaat van een overeenkomst gesloten door wereldleiders in 1992 in Rio de Janeiro. Het ging bij de desbetreffende 'Earth Summit' (topconferentie) om een allesomvattende strategie voor duurzame ontwikkeling. Het CBD kent een drieledige doelstelling, te weten het behoud van biodiversiteit, het duurzaam gebruik ervan en eerlijk gebruik van genetische bronnen.

De CBD heeft geleid tot een biodiversiteitsstrategie van de Europese Commissie. Natura 2000 maakt onderdeel uit van die biodiversiteitsstrategie. De strategie van de Europese Commissie is ambitieuzer dan het stoppen van de achteruitgang, want die is gericht op een zeker herstel. Dat herstellen lukt vooralsnog niet, ook niet in Nederland, zoals de Mid Term Review van het CBD laat zien (ministerie van EZ, 2014). De achteruitgang zet bijvoorbeeld nog door voor vogels van de agrarische landschappen. Recentelijk is er tevens de grote achteruitgang in aantallen insecten (Hallman et al. 2017). Het CBD levert een fundament en internationaal referentiekader voor gebiedsbescherming, uitgaande van een overkoepelende stelselvisie: wettelijke vastlegging van nationale parken en andere natuur- of landschaps-beschermde gebieden en de bijbehorende basisfinanciering hiervan. Nationale parken vormen daarvan in het algemeen de hoekstenen. Hiermee geeft de CBD een sterke basis voor (a) een regierol voor nationale overheden als de verdragspartijen bij de CBD en (b) het explicieter benoemen van natuurbescherming als het primaire doel van nationale parken (andere beheerdoelen worden dus zeker niet uitgesloten).

Met de ondertekening van de CBD verplichten overheden zich tot het zorgen voor adequate financiering van hun biodiversiteitsbeleid, inclusief beschermde gebieden. Andere financieringsbronnen zijn goed denkbaar en worden aangemoedigd, maar staten blijven eindverantwoordelijk. Nederland heeft het CBD ondertekend en heeft daarmee de verplichting op zich genomen om de biodiversiteit te beschermen. Ze kan daarin volgend zijn op de acties die door de Europese Commissie worden ondernomen in het licht van dit verdrag, maar ze kan eventueel ook extra maatregelen nemen die specifiek gericht zijn op de Nederlandse context.

IUCN biedt voor het naleven van de CBD een (weliswaar gezaghebbend) standaardmodel aan. Landen kunnen dit echter naar eigen inzicht aanpassen. Het wettelijk en beleidskader van een land is daarmee uiteindelijk bepalend voor de te hanteren standaard en een land kan daarbij dus in meer of mindere 
mate de IUCN-standaard volgen (Dudley, 2008). Grote afwijking van de IUCN-standaard kan de geloofwaardigheid natuurlijk wel ondermijnen. IUCN kan zich hoogstens uitspreken tegen oneigenlijk gebruik van de IUCN categorieën. De IUCN gebruikt een in 1978 ingevoerde en in 1994 aangepaste categorisering voor beschermde gebieden met zes verschillende categorieën: Ia Strikt natuurreservaat, Ib wildernisgebied, II nationaal park, III natuurmonument, IV natuurreservaat, $\mathrm{V}$ beschermd landschap en $\mathrm{VI}$ regionaal landschap (zie Bijlage 1). Elk land kan een keuze maken voor welke categorie zij een gebied aanmelden bij de WDPA (World Database on Protected Areas), een gezamenlijk initiatief van UNEP en IUCN. Categorieën worden overigens niet 'aangevraagd' bij IUCN, maar hoogstens aangemeld. Een overheid of beheerder kan bij het aanmelden van een gebied voor de WDPA zowel de categorie volgens eigen wetgeving als de in diens ogen bijbehorende IUCN-categorie aangeven.

De gebiedscategorieën van de IUCN zijn geen doel op zich maar een middel, een generiek planningsen management-instrument voor de ( mix van) beheerdoelstellingen (management objectives) die voor een beschermd gebied zijn te onderscheiden. Het onderscheid naar IUCN-categorieën is van belang omdat de gebieds- en beheermanagementcategorieën van de IUCN zich op hun beurt laten combineren met governance-typen. Dit resulteert in een zogenaamde IUCN-matrix. Daarbinnen is elke combinatie van categorie en type denkbaar.

Het belangrijkst is dat de filosofie áchter de IUCN-categorieën (de 'rationale', met het differentiëren op basis van beheerdoelstellingen) bewuster als uitgangspunt wordt genomen. Met andere woorden: de geest ervan is belangrijker dan de letter, vooral in de bijzondere context van een overbevolkt en intensief benut klein land als Nederland.

Governance en good governance van beschermde gebieden krijgt binnen de IUCN ongeveer sinds vijftien jaar aandacht (Borrini-Feyerabend et al. 2013; IUCN, 2003a en IUCN 2003b). Governance in beschermde natuur- en landschapsgebieden bestaat uiteraard langer: er zijn altijd al beslissingen genomen over beschermde gebieden. Wat nieuw is, is de relatief grote aandacht die governance sinds 2003 geniet, waarbij toevoegingen zijn gedaan als het gaat om zichtbaarheid, het articuleren van concepten en monitoring en evaluatiepraktijken.

De IUCN-richtlijnen voor het toepassen van beschermde ruimtelijke ordening voor de onderscheiden categorieën vermelden dat beschermde gebieden van alle categorieën kunnen worden bestuurd (en in eigendom kunnen zijn van) door overheidsinstanties, ngo's, gemeenschappen, inheemse volkeren, bedrijven en particuliere partijen - alleen of in combinatie (Dudley, 2008). De IUCN-richtlijnen voor beschermde wetgeving maken bovendien duidelijk dat governance een aparte overweging is naast eigendomsrecht, waarbij het belangrijk is te overwegen welke governance-benaderingen passend zijn voor bepaalde gebieden (Lausche, 2011). In feite kunnen beschermde gebieden elk type governance omvatten met een verscheidenheid aan eigendomsrechten, gedelegeerde rechten, pacht en overeenkomsten.

$\mathrm{Er}$ is geen ideaal type governance of governance-structuur of governance-model in het algemeen voor te beschermen gebieden. Afhankelijk van de context van de gebieden moet men bepalen welk type governance het meest geschikt is. Wel kunnen standaarden of principes voor de kwaliteit van governance (good governance) worden gegeven.

Onlangs heeft IUCN via de WCPA (2016a) een Groene-lijststandaard ontwikkeld bij wijze van kwaliteitskeurmerk voor beschermde gebieden en een bijbehorende gebruikershandleiding (IUCN en WCPA, 2016b) gepubliceerd om het bijbehorende programma te kunnen doorlopen en zo aan de Groene-lijstcriteria te voldoen. Naast natuurbescherming en natuurbehoud krijgen bestuur, management, monitoring en evaluatie, duurzame ontwikkeling en het versterken van de samenhang met economische, culturele, sociale en spirituele waarden in de Groene-lijststandaard volop aandacht (zie Figuur 1). Kortom, zaken die nu in het hart van de belangstelling van het PNP staan voor de ontwikkeling van een nieuwe standaard Nationale Parken nieuwe stijl. 


\section{The IUCN Green List Standard}

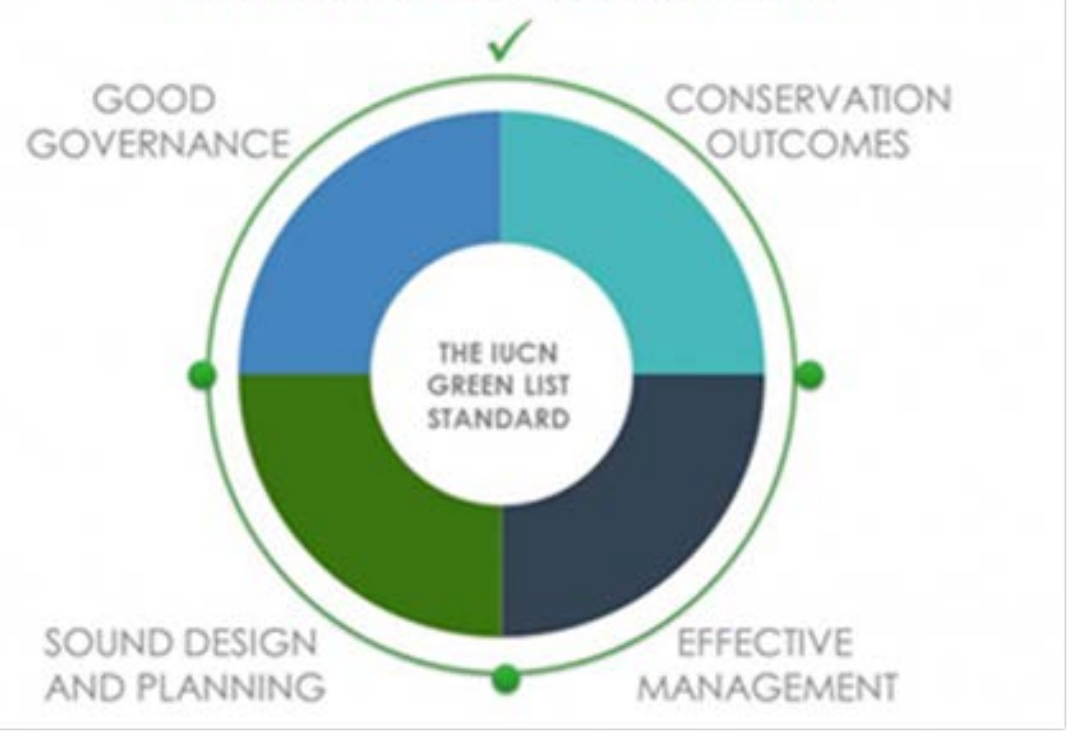

Figuur 1 De vier velden van de IUCN Groene-lijststandaard.

De Groene-lijststandaard is overigens niet bedoeld om zo veel criteria op te voeren en daarmee de eisen te verhogen om beschermd gebied of nationaal park te kunnen worden, maar vooral om handvatten te bieden voor gebieden die een kwaliteitsslag willen maken op velerlei gebied. Het gaat er dus vooral om dat een standaard een lonkend ontwikkelingsperspectief biedt. Natuurlijk kan het verkrijgen van een wettelijke status de gebieden zelf helpen. De criteria zijn niet bedoeld om verder door te selecteren. In het laatste geval zouden discussies kunnen ontstaan over in- en uitsluiting: wie hoort er wel en niet bij? Deze vraag blijft in deze quickscan buiten beschouwing.

Naast de IUCN-criteria heeft IUCN-Nederland ervoor gepleit om ook de CBD (Conventie inzake Biologische Diversiteit) te betrekken bij het uitwerken van de standaard. Een verwijzing naar relevante mondiale verdragen als de CBD ontbreekt tot nu toe bij de Nederlandse uitwerking van een standaard voor Nationale Parken van Wereldklasse. Nederland heeft deze Conventie (Biodiversiteitsverdrag) ondertekend. Het Rijk is er verantwoordelijk voor dat ons land zich aan de verdragsverplichtingen houdt. IUCN-Nederland ziet graag dat de nationale parken ook als hoekstenen van de Nederlandse bijdrage aan de CBD-doelen voor 2020 benoemd worden, inclusief de bijbehorende kwalitatieve criteria. Adequate financiering van de basisbehoeften van nationale parken hoort daarbij, als randvoorwaarde voor hun effectief beheer. Een stevig wettelijk kader inclusief basisfinanciering, met heldere definities van nationale parken én andere typen beschermde gebieden binnen een overkoepelende stelselvisie, horen daar volgens IUCN-Nederland ook bij. Nederland loopt in dit laatste internationaal niet voorop, maar zou met behulp van IUCN- en CBD-standaarden de achterstand snel goed kunnen maken. Wat betreft non-compliance van een lidstaat met betrekking tot de CBD wordt een zachte aanpak gevolgd: er staan geen sancties of straffen op het niet naleven van de CBDafspraken.

\subsection{Inspiratie: UNESCO-criteria en sociale en economische impactervaringen}

Naast de mogelijkheden die de Groene standaard volgens ons biedt voor het uitwerken van de standaard, kan ook inspiratie worden ontleend aan de criteria voor de UESCO-werelderfgoedgebieden. De Commissie Realisatie Natuurverkiezing (2017) deed de suggestie om voor de aanwijzing van de Nationale Parken (nieuwe stijl) alleen de aanwijzingscriteria van UNESCO-werelderfgoed te volgen. 
Deze commissie formuleert als kritiek op de IUCN-criteria voor beheermanagement en gebiedscategorieën dat deze onvoldoende passen bij de huidige discussie en zoektocht naar Nationale Parken nieuwe stijl. Ons inziens biedt de Groene-lijststandaard van de IUCN wel voldoende adequaat ontwikkelingsperspectief en zou dit gecombineerd kunnen worden met UNESCO-criteria.

Op zich is het interessant om de UNESCO-criteria in overweging te nemen. De criteria die de Commissie Realisatie Natuurverkiezing noemt, zijn overigens niet geheel overgenomen van UNESCO, maar lijken een eigen interpretatie van de commissie te bieden. Die criteria zijn volgens ons niet onderscheidend genoeg: de Blauwe Kamer zou bij wijze van spreken bij het hanteren van deze criteria ook tot Nationaal Park kunnen worden ingesteld. Een andere reden om de criteria van de Werelderfgoedlijst kritisch te benaderen, is dat UNESCO - in tegenstelling tot IUCN - wel inzet op planologische veiligstelling: UNESCO controleert streng op het waarmaken van de status. Zo is Dresden de status van werelderfgoed kwijtgeraakt omdat er een rondweg werd gerealiseerd in het UNESCO-gebied. Hetzelfde dreigt met St. Petersburg te gebeuren...

(https://www.theguardian.com/world/2007/sep/03/russia.architecture). UNESCO heeft daarmee een veel sterkere controle- en handhavingspositie dan de IUCN en in die zin loopt de vergelijking voor het overnemen van UNESCO-criteria hier dan ook enigszins mank, tenzij UNESCO of de IUCN mandaat krijgen om beleid te controleren en te handhaven. Het willen hanteren van 'een standaard' verplicht je om deze vast te leggen en te monitoren. Deze basis wordt in het buitenland veelal verankerd in wetgeving. We begrijpen dat het PNP geen jarenlang debat wil voeren over de standaard. Het Rijk en het IPO hebben hierin het voortouw.

Net als de Commissie Realisatie Natuurverkenning (2017) hebben ook wij ons laten inspireren door ervaringen met de Werelderfgoedgebieden. We leggen hierbij een link naar het werk van James Rebanks (Lake District World Heritage Project, 2009; Rebanks, 2012) voor Werelderfgoedgebieden. Voor Werelderfgoedgebieden is Rebanks nagegaan of de Wereld Erfgoedstatus kansen biedt voor economische en sociale ontwikkeling en opbrengsten (Lake District World Heritage Project, 2009). Voor 878 Werelderfgoed gebieden verspreid over de wereld heeft Rebanks in 2009 met vijftien verschillende criteria bepaald hoe de karakteristieken, motivaties en acties beoordeeld kunnen worden. Uit het onderzoek kwam naar voren dat maar 5 tot $10 \%$ van de gebieden door sociaaleconomische doelen wordt ingegeven. 70 tot $80 \%$ van de gebieden is puur gericht op cultuurbehoud en niet op een vorm van benutting van het erfgoed voor de sociaaleconomische ontwikkeling. lets minder dan $20 \%$ doet iets met een erfgoedeconomie, waarbij het vooral gaat over het verkopen van diensten en producten aan toeristen. Ongeveer 5\% combineert cultuurhistorisch behoud met economische aspiraties, door samenwerking met bedrijven ten behoeve van diensten en producten die verwijzen naar het werelderfgoed. Slechts enkele sites gebruiken het erfgoed echt actief als een socio-economische motor in de gebiedsprofilering en ontwikkeling. Een van de mooiste voorbeelden, genoemd in de analyse van Rebanks, is Blaenavon. Dit betreft een door Thatcher koud gesaneerde kolenmijn, die door het stadje en de mijnwerkers uit pure nood is omgevormd tot een Werelderfgoedlocatie. Een stad in verval is met de middelen die hier worden binnengehaald, omgevormd tot een florerend geheel, waar alles in het teken staat van de trotse geschiedenis van de industriële revolutie en de kolen die daarvoor nodig waren.

Alles overziend: de sociaaleconomische impact van Werelderfgoedgebieden is beperkt. In onderstaande afbeelding is het onderzoek van Rebanks verbeeld. 


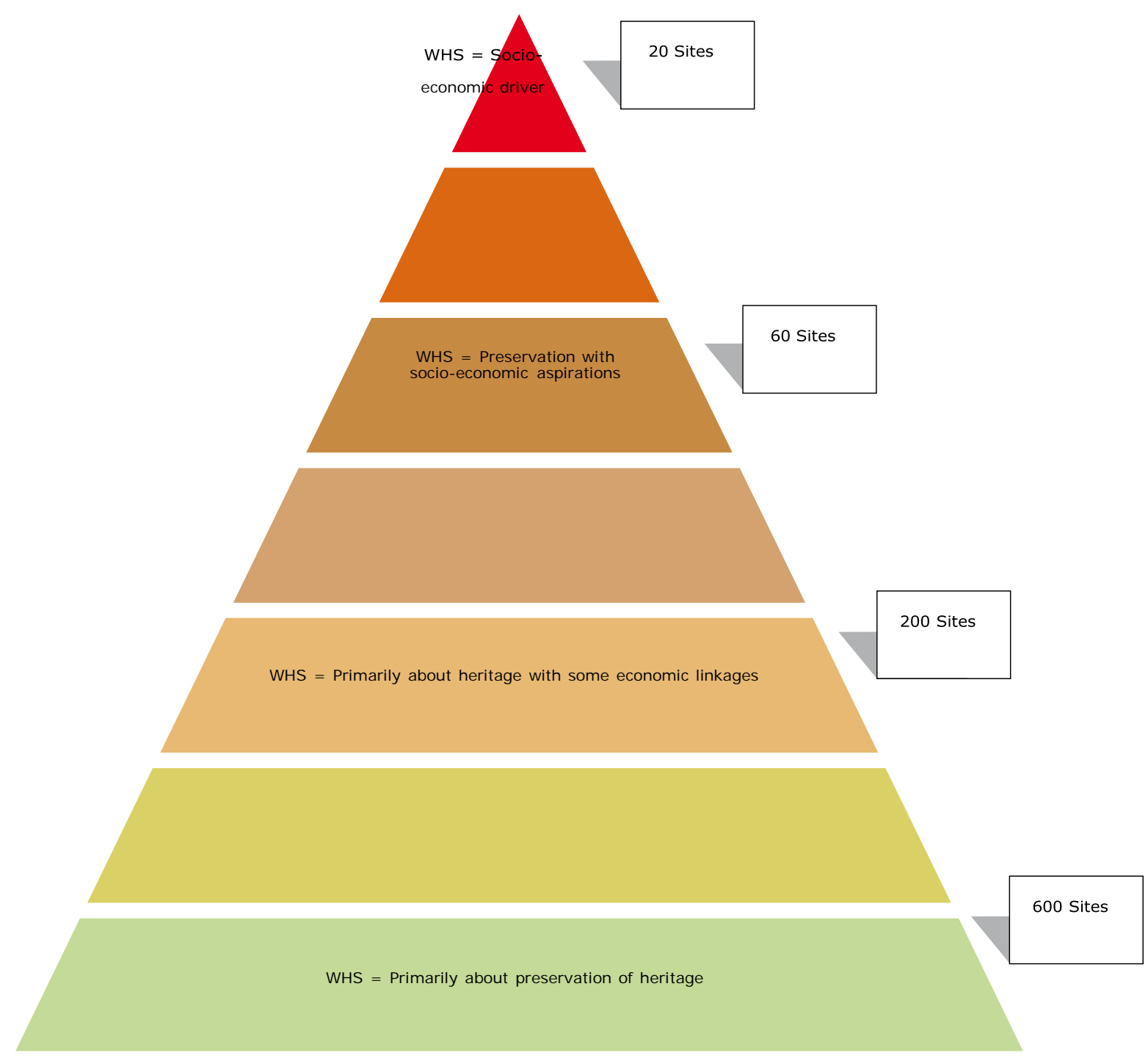

Figuur 2 Het samenspel tussen cultuurhistorisch behoud en sociaaleconomische ontwikkeling bij 800 werelderfgoed gebieden (Bron: James Rebanks, geciteerd in Lake District World Heritage Project, 2009).

Geconcludeerd kan worden dat binnen de Werelderfgoedstatus er verschillende ambitieniveaus op nagehouden kunnen worden. Een andere conclusie is dat de gebieden met sociaaleconomische doelen er niet nog een label of merk bovenop krijgen om zich van de andere gebieden te onderscheiden; zij blijven alle Werelderfgoedgebieden. De differentiatie aan invullingen van de ambitieniveaus binnen de Werelderfgoedstatus blijft daarmee onder één noemer. Wat deze Figuur van Rebanks voor de Werelderfgoedgebieden voor de standaard van de Nationale Parken nieuwe stijl kunnen betekenen, wordt verderop in deze rapportage duidelijk.

\subsection{Conclusies}

Zoals aangegeven, is sprake van verschuivingen in de IUCN-standaarden. Waar voorheen alleen een standaard voor een indeling op natuurbeheerdoelstellingen was ontwikkeld, is daar sinds enkele jaren een standaard voor governance aan toegevoegd. Dit heeft geresulteerd in een geheel nieuw, overkoepelend wereldwijd keurmerk voor beschermde gebieden: de IUCN Green List. De Green List is recent (2016) en speelt tot nu toe een heel bescheiden rol. Het bevat wel een positief kwaliteitsoordeel. Voor de zes categorieën voor beschermde gebieden van IUCN is dit niet het geval, dat is een geheel neutrale indeling. 
Landen bepalen zelf welke onderscheiden categorieën van de IUCN-standaard zij opnemen in nationale of regionale regelgeving of beleid en hoe bijvoorbeeld de rijksoverheid zich daarbij verhoudt tot andere overheden, marktpartijen, maatschappelijke organisaties en bewoners. Tussen landen zijn daarbij ook verschillen waar te nemen als het gaat om zonering in nationale parken of toegestane activiteiten in nationale parken. Lidstaten hebben dus zelf 'implementatieruimte' om te bepalen hoe de categorieën voor beschermde gebieden landelijk worden ingevoerd.

De ultieme governance bestaat overigens niet, omdat er nooit volledige synergie is te bereiken tussen ecologische kwaliteit en andere thema's als toerisme, merkontwikkeling, beheer, financiering etc. Het gaat er om dat er lerende governance ofwel adaptief management ontstaat, gebaseerd op flexibiliteit, alsmede adaptief en reflexief vermogen in de onderliggende samenwerking. 


\section{Observaties en inspiraties vanuit het nationale parkenbeleid in het buitenland}

\subsection{Observaties na de quickscan}

We beschrijven nu enkele observaties van verschillen en overeenkomsten met het nationale parkenbeleid of beleid voor beschermde gebieden in het buitenland, die relevant kunnen zijn voor discussies die nu worden gevoerd over de Nationale Parken van Wereldklasse. De organisatorische, juridische of geografische situatie voor buitenlandse parken is vaak anders dan voor de Nederlandse (SNP, 2010). Toch zijn sommige buitenlandse ervaringen, al dan niet in aangepaste vorm, ook in Nederland goed bruikbaar.

\subsection{Ruimtelijke strategieën: zonering en het instellen van bufferzones rond Nationale Parken}

Veel landen (denk bijvoorbeeld aan Frankrijk, Italië, Spanje, Zwitserland) hebben in hun juridische regelgeving zowel nationale parken als natuurparken opgenomen (zie Bijlage 3). Deze landen hebben een overkoepelende stelselvisie op beschermde gebieden: een stevig wettelijk kader inclusief basisfinanciering, met heldere definities van nationale parken én andere typen beschermde gebieden. In onze regelgeving ontbreekt de aanwijzing van gebieden die onder "beschermd landschap", categorie 5 vallen, sinds nationale landschappen geen onderdeel meer vormen van het nationaal beleid vanaf 2012 (Zie lenM et al. 2012. Structuurvisie Infrastructuur en Ruimte).

In onderstaande beschrijving wordt aangegeven hoe andere lidstaten ruimte binnen categorie 2 zelf vinden. De nationale parken in Spanje en Zwitserland kennen zogenaamde bufferzones, waar de lokale bevolking woont en werkt. In Spanje (http://www.parks.it/world/ES/Epage_menu.php?id=12) wordt samen met een Nationaal Park een "perifere beschermingszone" opgericht die grenst aan het grondgebied van het park om zijn waarden over te brengen naar de omliggende gebieden en de ecologische impact van buitenaf op het grondgebied van het park te verminderen. In I talië (http://www. parks.it/indice/Efaq.aree.protette.html) wordt er binnen nationale parken een zonering met vier verschillende zones op na gehouden:

- Zone A: Strikt natuurreservaat. Geen menselijke activiteiten toegestaan behalve voor wetenschappelijk onderzoek.

- Zone B: Algemeen Reserve. Alleen traditionele beroepen zijn toegestaan en het toerisme wordt door het park verzorgd.

- Zone C: Planning van toerisme en agrarische systemen die door het park worden toegelaten.

- Zone D: Ontwikkeling. Bevat bebouwde gebieden, potentieel duurzame activiteiten.

Ook buiten Europa hebben veel landen iets dergelijks (zie bijvoorbeeld Dudley, 2008, pag. 10).

De nationale parken in Engeland en Wales hebben een andere opzet dan parken in de rest van de wereld (denk bijvoorbeeld aan Spanje, Zweden of Frankrijk). In die landen is het grondgebied van het park vaak eigendom van de staat. In Engeland en Wales worden de ruim tien nationale parken bewoond. De mens hoort in deze parken bij de leefomgeving. Grondgebied dat privé-eigendom is, maakt dan ook onderdeel uit van het nationale park. Ruim twintig procent van het oppervlak van Wales valt onder een nationaal park. In Engeland is dat ruim tien procent. De nationale parken in het Verenigd Koninkrijk zijn meer als categorie 5 gebieden te beschouwen, het concept lijkt dan meer op MaB reserves. 
Hieruit kan worden opgemaakt dat landen die strak begrenzen, er meerdere zones op nahouden om geleidelijke overgangen te creëren. Landen die minder strak begrenzen, houden er een ruimtecategorie op na opdat niet op voorhand allerlei activiteiten worden uitgesloten.

\subsection{Economische keuzes}

Voor de financiering van Nationale Parken zien we dat er landen zijn waarbij de Nationale Parken grotendeels door de overheid worden gefinancierd, zoals Zweden, Spanje en het Verenigd Koninkrijk (Bijlage 3). Daarnaast zien we dat een deel van de financiering voor natuurbeheer via de eigenaren van de grond verloopt en daarmee ten goede komt aan de natuur in het nationaal park. In bijna alle bestudeerde landen is er een duidelijke wettelijke basis en juridisch kader in de standaard om verschillende typen natuurgebieden in te stellen. Die sterke wettelijke basis betreft niet enkel de wettelijke bescherming van de natuur, maar ook de juridische status van de organisatievorm van nationaal park. Een sterke juridische status gaat veelal gepaard met een sterke rol voor de rijksoverheid en voor het inzetten van overheidsmiddelen voor de natuurgebieden. Als de basis van een Nationaal Park qua bescherming en organisatorische status goed is geregeld, ontstaat er meer ruimte voor meer governance-vormen in de publiek-private samenwerking. Er wordt immers een basis geboden vanuit overheden waar private partijen op kunnen vertrouwen. Ook wettelijke bescherming kan vertrouwen bieden, omdat al van tevoren duidelijk is waar wel en niet iets mogelijk is. Zo kan een wettelijke basis een standaard bieden die juist een mogelijke bottom-up aanpak voor het instellen van nationale parken mogelijk maakt.

In het Verenigd Koninkrijk wordt het bestuur rechtstreeks betaald door de staat. Vroeger was er een soort verdeelsleutel waarbij een gedeelte door de regio en een gedeelte door de staat betaald werd ${ }^{2}$. Een aantal nationale parken in het buitenland streeft naar inkomsten voor de nationale parken via regionale of lokale ruilhandel, wat later in het rapport wordt toegelicht. Voor Schotland zijn in 2000 vier doelen voor nationale parken gepubliceerd. Deze komen sterk overeen met de doelstellingen van de nationale parken in Engeland en Wales (http://www. parks.it/world/UK/Eindex.php):

1. Het behouden en vergroten van de natuur en cultureel erfgoed van het gebied.

2. Het promoten van duurzaam gebruik van de natuurlijke bronnen van het gebied.

3. Het promoten van begrip en beleving (inclusief beleving in de vorm van recreatie) van de speciale kwaliteiten van het gebied bij het publiek.

4. Het promoten van duurzame economische en sociale ontwikkeling van de in het gebied levende gemeenschappen.

Veel parken in Italië hebben naast overheidsfinanciering ook zelf-financierende mechanismen, door het aanbieden van toeristische voorzieningen, milieueducatie en de verkoop van ambachtelijke producten etc. Nationale parken stellen een sociaal en financieel strategisch plan voor de lange termijn op. I talië maakt voor de financiering ook gebruik van Europese subsidie, bijvoorbeeld vanuit het 'LIFE+ nature en biodiversity'-programma.

Nationale parken worden in Zwitserland ingesteld op basis van de inzet van de lokale bevolking. Met hun ideeën werken de mensen mee aan de toekomst van de regio. Tot slot bepalen zij zelf of ze deel willen uitmaken van een nationaal park of niet. Deze grassroots-aanpak is uniek in de wereld. In Zwitserland erkennen de federale autoriteiten alleen parken die zijn gebaseerd op regionale initiatieven en de steun krijgen van de lokale gemeenschap. Regionale initiatieven worden ondersteund en gemonitord door de betrokken kantons. Om het park-etiket te krijgen en financiële steun te ontvangen, moet aan belangrijke criteria worden voldaan: hoge natuurlijke en landschapswaarden en minimale beïnvloeding door infrastructuur of grondgebruik, samen met democratische legitimatie. Daarnaast moeten ruimtelijke ordening en financiering op de lange termijn verzekerd zijn en moet er een parkmanagementstructuur zijn. In de aanvraagfase ontvangen de parken een voorlopig kandidaatlabel. Het specifieke karakter van het model van Zwitserse parken is hun bottom-up ervaring, die uniek is in de wereld, waarin het de burgers zelf zijn als aanstichters van

\footnotetext{
${ }^{2}$ http://reizen-en-recreatie.infonu. nl/europa/99227-nationale-parken-van-engeland-en-wales. html
} 
de instelling van nationale parken. Ze definiëren en ondersteunen duurzame ontwikkelingsprojecten. De projecten worden ondersteund door de verschillende partners, zorgen voor uitwisseling, flexibel beheer en resultaten ter bevordering van de hele regio. Er is daarmee aandacht voor:

- Cultuur en traditie: de identiteit van de parken;

- Raamwerk condities: betrekken van overheden bij de regio;

- Lokale betrokkenheid: leven in de parken.

Interessant is dat de nationale parken in het Verenigd Koninkrijk de plicht hebben om te streven naar economisch en sociaal welzijn van de lokale gemeenschappen binnen hun grenzen. Boeren vormen in de nationale parken van het Verenigd Koninkrijk een belangrijke groep van landeigenaren.

Het SNP haalde in 2011 de Verenigde Staten als voorbeeld aan: “In de Verenigde Staten bestaat lokaal een actieve samenwerking met de private sector. Het Boston Harbor I slands National Park bijvoorbeeld herinvesteert private inkomsten in de activiteit waarmee ze verdiend zijn en stort het overblijvende deel in een fonds voor algemene financiële ondersteuning van het park. Op de website kunnen bedrijven terecht op de pagina 'Doing business with the park', waar onder andere de criteria te vinden zijn waaraan commerciële activiteiten moeten voldoen. Deze zijn tamelijk algemeen. Activiteiten moeten bijvoorbeeld passen bij de natuurdoelstellingen en de identiteit van het landschap, voldoen aan de bouwvoorschriften en zo mogelijk aansluiten bij andere projecten." (SNP, 2011)

En:

“De Verenigde Staten van Amerika kent een enorm aantal nationale parken. Voor de meeste hiervan wordt entreegeld gevraagd. Met dit geld uit het toerisme beheert de overheid de nationale parken. Het verblijven in nationale parken is ook mogelijk. Het heffen van entreegeld is in Nederland vaak niet mogelijk vanwege de vele ontsluitingen van een park. In de Verenigde Staten zijn de nationale parken 'overheid', zodat ze niet zelf fondsen mogen werven. Overeenkomsten met de private sector zijn ondergebracht in stichtingen. De National Parks Foundation, de evenknie van het Samenwerkingsverband Nationale Parken, rekent onder andere American Airlines en Discovery Channel tot haar 'proud partners'. De Foundation haalt jaarlijks ruim 50 miljoen euro binnen." (SNP, 2011)

In Schotland mogen ondernemers onder vrij strenge voorwaarden de naam van het Cairngorms National Park gebruiken in ruil voor een vermelding als 'Cairngorms National Park Ambassador' op de website van het park. De voorwaarden worden vastgesteld door een speciale 'Brand Management Group', waarin de staf van het park, de Kamer van Koophandel en gemeenten hun vertegenwoordigers hebben. Criteria voor vermelding van de parknaam verschillen per sector, maar komen erop neer dat het betrokken bedrijf mens- en milieuvriendelijk onderneemt. Toeristischrecreatieve ondernemers moeten bijvoorbeeld voldoen aan bepaalde gedragsregels en in het bezit zijn van een milieukeurmerk (Visit Scotland-certificaat). Producten mogen alleen de naam van het park dragen als ze uit het park afkomstig zijn en milieuvriendelijk zijn geproduceerd. Zo ontwikkelt de Brand Magement Group de naam van het nationaal park tot een sterk merk (SNP, 2011). Duitsland heeft een label voor meerdere categorieën van natuur: Nationale Natuurlandschappen (Nationale Naturlandschaften). Dit label is een paraplu waar drie categorieën in Duitsland zijn ondergebracht: Nationale Parken, Natuurparken en Biosfeerreservaten. De ontwikkeling van het label is georganiseerd met Europarc Germany in samenwerking met de VDN (Verband Deutscher Naturparke) met steun van het Bundesministerium für Umwelt, Naturschutz und Reaktorsicherheit (BMU). De eigenaar van het merk/label is Europarc Germany. Alle gebieden die het label willen gebruiken voor merkontwikkeling kunnen hiervoor toestemming krijgen, onafhankelijk of ze nu lid zijn van Europarc Germany of niet. Ambassadeur van de Nationale Natuurlandschappen is Angela Merkel die de volgende uitspraak deed: "The Federal government supports the roof-brand Nationale Naturlandschaften, because we want to strengthen the high regard of the large protected areas by this presentation." (Ostermann, 2013)

Voor de Nationale Natuurlandschappen gebruikt Duitsland als label een kleurenstip. Afhankelijk van de beleidscategorie of de karakteristieke typering van het gebied worden verschillende kleuren stippen gehanteerd, ofwel een soort 'eenheid in verscheidenheid'. 


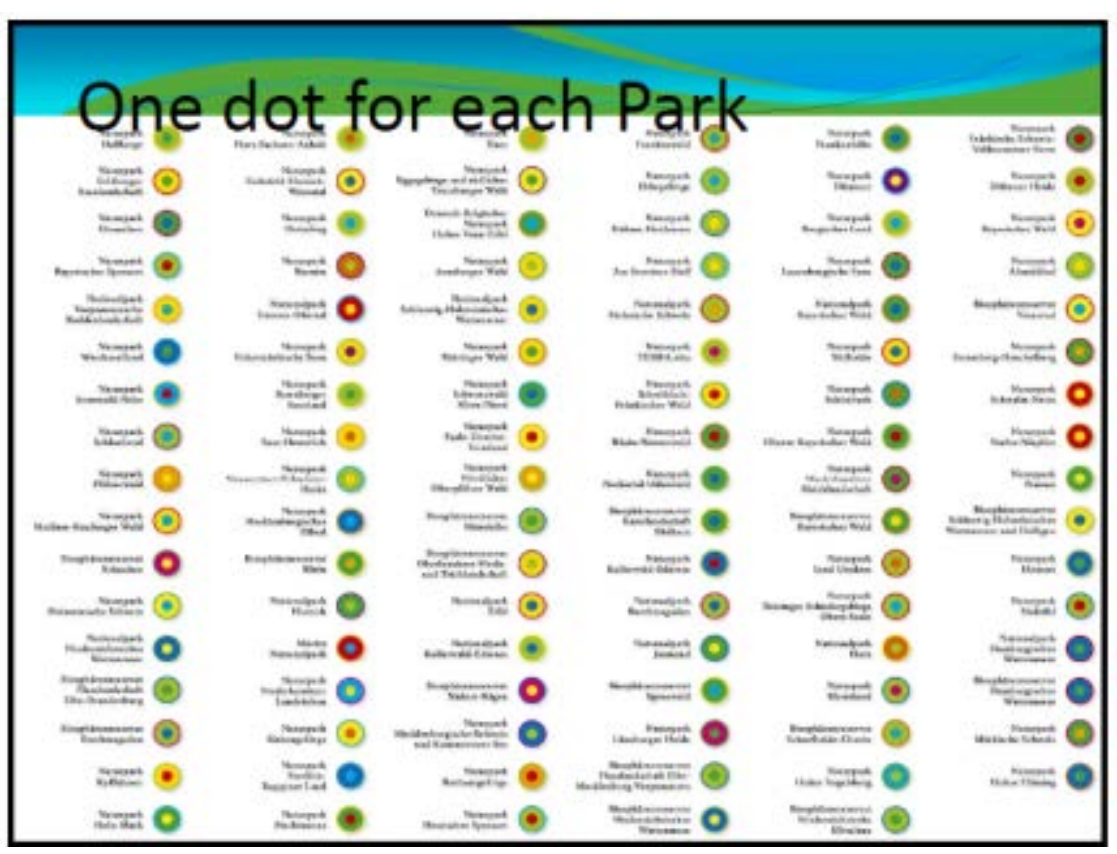

Figuur 3 Het gebruik van kleurenstippen in het Duitse Nationale Parkensysteem, om de eenheid alsmede de verscheidenheid te benadrukken (Bron: Ostermann, 2013).

\subsection{Governance-modellen}

De internationale voorbeelden laten zien dat er verschillende ruimtelijke strategieën bestaan en economische keuzes zijn gemaakt die van grote invloed zijn op de governance-structuren. Op basis van de quickscan komen wij tot de volgende modellen voor ruimtelijke strategie:

1) Gebieden worden aangemeld onder een strenge IUCN-categorie, maar binnen en buiten het gebied wordt gewerkt met een zonering die verschillende ontwikkelpotenties biedt;

2) Gebieden worden aangemeld onder een lichte IUCN-categorie, waardoor het niet of minder noodzakelijk is om met een zonering te werken.

Omtrent de financiering van nationale parken zijn er meerdere mogelijkheden, vaak afhankelijk van de politieke keuzes die worden gemaakt. De financiën kunnen puur en alleen van overheden afkomstig zijn. Dit is vaak het geval wanneer natuur als een collectief goed wordt beschouwd en vrij toegankelijk moet zijn, waarvoor de overheid verantwoordelijk is. De financiering kan ook gericht zijn op de eigenaren van de terreinen die in de nationale parken liggen. Een andere opvatting is dat de gebruikers van het nationale park als uitbaters dienen te betalen. Weer een andere opvatting is dat er sprake dient te zijn van gedeeld eigenaarschap en gemeenschappen als geheel dragers van de nationale parken dienen te zijn. Uiteraard zijn ook nog diverse mixen van het bovenstaande denkbaar. Een park dat door ondernemers wordt gedragen, heeft uiteraard een andere vorm van governance nodig dan een park waarin de provincie sterk aan de financiering bijdraagt.

Naast volledige financiering door overheden ${ }^{3}$ zijn er twee andere modellen te onderscheiden: 1) Het model van 'return on cash flows': aan het nationale park is geld te verdienen. Dat geld blijft niet alleen in het nationale park zelf; ook anderen buiten het Nationaal Park worden er beter van. Een deel van het geld komt wel naar de nationale parken. Een voorbeeld dat bij dit model past, is het massatoerisme.

2) Een ander economisch model betreft het model van de regionale economie (regional exchange trade economy), ofwel een economie die is gebaseerd op directe of indirecte ruilhandel. Vroeger werden de goederen en diensten in een lokale ruileconomie direct geruild. Tegenwoordig betalen de

3 Het model van volledige overheidsfinanciering laten wij hier verder buiten beschouwing omdat daar geen noodzaak is voor gebiedsbranding gekoppeld aan pps-vorming. 
deelnemers in een lokale ruileconomie elkaar meestal in een interne munt (complementaire munteenheid, complementary currency), zodat de activiteit niet beperkt hoeft te blijven tot een-opeen ruilhandel. I edere verdiende euro wordt meerdere keren in het gebied zelf uitgegeven. De boer heeft bijvoorbeeld 'natuurhamburgers'. Het restaurant koopt deze en verkoopt het door aan klanten. Met het geld koopt het restaurant weer honing uit het gebied.

Alle combinaties van ruimtelijke strategieën en economische keuzes lijken mogelijk voor nationale parken. Toch zijn er logische keuzes te maken: een keuze voor massatoerisme gaat veel beter samen met return of cash flows (er mag geld uit de regio gaan; maar er moet ook wat geld naar de regio komen) dan met regionale exchange. Een privaat gestuurd park komt beter uit de verf als er sprake is van een zonering, waarin het kerngebied voor de natuur is ingebed in een specifieke landschapscategorie, ofwel waar de zone bepaalt in welke specifieke landschapscategorie het valt.

De verschillende governance-modellen die aangetroffen worden in buitenlandse voorbeelden hebben veel te maken met ruimtelijke strategie en economische keuzes. We werken deze hieronder verder uit.

\section{Ruimtelijke strategieën en governance}

In ruimtelijk opzicht zien we voorbeelden van ecologische kerngebieden die soms vrijwel zonder bufferzones beheerd moeten worden. Dit komt voor als een gebied in een peri-urbaan landschap is gelegen met een hoge druk op de ruimte of als het bestaat uit een heel specifiek habitat die niet of nauwelijks te bufferen valt. In die situatie is er een inherente spanning tussen de ecologische kwaliteiten en het beleefbaar maken of de commodificering (alles wordt onderhevig gemaakt aan marktwerking: excursies, rondvaarten met fluisterboten). Het gevolg is dat alle relaties gedefinieerd kunnen worden in termen van vraag en aanbod ervan. In die situatie is de governance gericht op onderhandelen en spelen compensatiemechanismen en mitigerende maatregelen een belangrijke rol. Deze governance lijkt enkel goed te functioneren als er een sterke overheid aan tafel zit, als de kernkwaliteiten van het park in hoge mate bij wet beschermd zijn en als er ook ruimte gevonden kan worden voor compensatiemaatregelen.

Anderzijds zien we voorbeelden van interne en externe zonering die soms wel aanleiding geven tot vier verschillende ruimtelijke zones: de kern, een gebied met belevingsactiviteiten, een zone met voorzieningen en een wijdere omgeving waar economie en ruimtegebruik rekening houdt en inspeelt op het nationale park. In deze situatie functioneert doorgaans per niveau een aparte governancestructuur: meerdere governance-arena's op verschillende schaalniveaus die in elkaar haken. Voor elke laag is er een andere configuratie van beslissers en verantwoordelijken, terwijl ook de participatie door private investeerders en ondernemers eenvoudiger in goede banen te leiden is. Het lijkt erop dat als het gebied meer is opgedeeld in zones, er ook sprake is van een sterker merk, omdat de commerciële partijen daar veel baat bij hebben.

\section{Economische keuzes en governance}

Qua economie kunnen er eveneens twee stromingen onderkend worden, die overigens niet altijd zo scherp van elkaar gescheiden zijn. Beide werken differentiërend op de governance. De ene stroming, die we hier 'return on cash flows' noemen, komt voort uit het idee dat een nationaal park bijdraagt aan de omzet van de recreatieve en toeristische sector en dat een deel van de winsten daarvan terug zouden moeten vloeien naar het gebied ${ }^{4}$. Dit kan plaatsvinden door middel van een soort opslag van diensten en producten die terugvloeien naar het park ofwel zijn beheersorganisaties, een soort baatbelasting dus. In deze stroming is (massa)toerisme een belangrijke bron van inkomsten en zal derhalve verwelkomd worden. De governance die hier bij hoort, is gebaseerd op een sterke rol van de overheid en is ook juridisch van aard in de zin dat veel onderlinge verhoudingen formeel geregeld moeten worden. Gewerkt moet worden met contracten en er moet een scherp onderscheid gemaakt worden met de reguliere belasting.

De andere stroming vindt men in Italië, maar ook elders. Dit betreft het model van 'een regionale economie', die in haar uiterste consequentie zelfs kan leiden tot een lokale munt. Het idee is dat elke euro zo lang mogelijk vastgehouden moet worden in een gebied, door hem telkens weer lokaal te

\footnotetext{
${ }^{4}$ Zie de publicaties van Tom Bade en zijn website www.tripleee.nl
} 
besteden. De bezoeker die in een museum komt, koopt taart bij de koffie die om de hoek is gebakken en het museum besteedt die opbrengst om lokale producten in te kopen voor hun museumshop en zo verder. Ook worden bepaalde symbolen heel sterk doorgevoerd, zoals het logo van Parco d'Abruzzo (de bruine beer), dat overal in de streek gebruikt wordt en veel positieve associaties heeft voor de bewoners van de streek. De branding in een dergelijk gebied is sterker, omdat het meer dan in het model van 'cash flow return' is gebaseerd op regionale identiteit en trots en omdat er meer lokale mensen van profiteren in plaats van investeerders van buiten het gebied. De economie is informeel van aard, waarin een gunfactor een belangrijke rol speelt. In feite is er dan sprake van een informeel sociaal contract, gebaseerd op een sterke regionale traditie en cultuur. Veel van de voorbeelden uit de praktijk van Hans Kamerbeek (2015) gaan deze richting op, maar de regionale verbinding is meestal beperkt ontwikkeld.

Wanneer we de ruimtelijke strategieën combineren met de economische keuzes, dan zijn hier verschillende bijpassende governance-modellen voor weer te geven, waarbij ieder model zowel voorals nadelen biedt. Het is overigens niet de bedoeling om een van de hieronder geschetste modellen te omarmen om toe te passen voor alle nationale parken, maar het biedt mogelijkheden tot differentiatie tussen de nationale parken met de governance-modellen, al naargelang de context en de keuzes die voor een nationaal park worden gemaakt.

Tabel 1 Verschillende governance-modellen die het gevolg zijn van economische keuzes en ruimtelijke strategieën.

\begin{tabular}{|c|c|c|}
\hline $\begin{array}{l}\text { Ruimtelijke } \\
\text { strategieën/Economische } \\
\text { keuzes }\end{array}$ & $\begin{array}{l}\text { Return of cash flows (geld } \\
\text { gaat gebied uit, deels ook } \\
\text { in) }\end{array}$ & $\begin{array}{l}\text { Gesloten regionale economie: inzet } \\
\text { op } \\
\text { medeverantwoordelijkheid/wederzij } \\
\text { dse afhankelijkheid }\end{array}$ \\
\hline $\begin{array}{l}\text { Keuze voor zoneringen: } \\
\text { zones bepalen welke } \\
\text { activiteiten wel en niet } \\
\text { kunnen }\end{array}$ & $\begin{array}{l}\text { Governance gebaseerd op } \\
\text { scherp omschreven } \\
\text { competenties en } \\
\text { verantwoordelijkheden. } \\
\text { Voordeel: veel speelruim te } \\
\text { voor alle partijen binnen hun } \\
\text { zone } \\
\text { Nadeel: juridisch van aard }\end{array}$ & $\begin{array}{l}\text { Governance is inclusief en deels ook } \\
\text { informeel, gebaseerd op econom ische } \\
\text { wederkerigheid. } \\
\text { Voordeel: branding en sociale economie } \\
\text { vloeien in elkaar over: groot draagvlak } \\
\text { Nadeel: zonering is lastig te maken, want } \\
\text { wordt snel gezien als belemmerend door } \\
\text { actoren }\end{array}$ \\
\hline $\begin{array}{l}\text { Geen zoneringen: alles } \\
\text { wordt onderhandelbaar } \\
\text { vooral tussen overheden. } \\
\text { Toegestane activiteiten } \\
\text { dienen elders } \\
\text { gecompenseerd te } \\
\text { worden. }\end{array}$ & $\begin{array}{l}\text { Kan alleen werken met zeer } \\
\text { slagvaardige governance en } \\
\text { sterke en ook precieze } \\
\text { wettelijke bescherming } \\
\text { gecombineerd met marketing } \\
\text { aanpak. } \\
\text { Voordeel: zeer ruimte- } \\
\text { efficiënt, korte lijnen tussen } \\
\text { actoren } \\
\text { Nadeel: juridisch van aard, } \\
\text { zeer kwetsbare constructies, } \\
\text { discussies vooral over geld, } \\
\text { kan snel omslaan naar } \\
\text { wantrouwen }\end{array}$ & $\begin{array}{l}\text { Gebaseerd op vertrouwen tussen } \\
\text { actoren, sterk gevoel van mede- } \\
\text { eigenaarschap en } \\
\text { medeverantwoordelijkheid. Governance } \\
\text { is veranderlijk naar de aard van besluit } \\
\text { of proces. } \\
\text { Voordeel: Iedereen profiteert van de } \\
\text { naam en faam van het natuurlijk kapitaal } \\
\text { in het NP. } \\
\text { Nadeel: intransparant voor mensen } \\
\text { buiten de governance arena }\end{array}$ \\
\hline
\end{tabular}

De vier mogelijke modellen worden nu kort toegelicht. Linksboven vinden we de variant dat return on cash flows combineert met verschillende zones waarin telkens meer en andere soorten activiteiten kunnen plaatsvinden. In deze variant moet er per zone worden vastgelegd wat er wel en niet toegestaan is. Heel simpel gesteld, wordt in de buitenste zones het geld verdiend waarmee in de kern ecologische beheermaatregelen kunnen worden gefinancierd. Daarvoor moeten de winsten die toe te schrijven zijn aan de aanwezigheid van het park worden afgeroomd door middel van contractuele afspraken. Het kan daarbij complicerend werken dat investeerders heel goed van buiten het gebied 
kunnen komen (bijvoorbeeld hotelketens of een reisorganisatie) en geen lokale binding hebben. Het parkmanagement heeft de taak om ervoor te zorgen dat de activiteiten in de buitenste zones de kwaliteiten in de binnenste zones niet bedreigen en liefst nog versterken. Daarvoor is het nodig dat er per zone bekeken wordt wie er aan tafel zit als het gaat om besluitvorming en wat er onderling moet worden vastgelegd en geregeld ten aanzien van geld en eventuele milieu- en recreatiedruk. Vooral is er ook consensus nodig over de positieve werking van de aanwezigheid van een natuurpark op de omzet van voorzieningen en diensten. Als de verschillende actoren in de zones deze consensus zien als een groeimodel voor de samenwerking en niet enkel als de status quo, dan is synergie mogelijk tussen behoud van biologische diversiteit en economische revenuen.

De variant die return on cash flows combineert met de situatie zonder zonering, of met een zeer beperkte interne zonering (linksonder in Tabel 1), vraagt om een bestuursmodel die in juridisch opzicht strak is geregeld. Alle actoren zitten in feite op elkaars lip, met alle voor- en nadelen van dien. In het gebied wordt geld verdiend door private partijen, die bereid zijn om een deel daarvan af te dragen ten faveure van het park. Eventuele beperkingen in diensten en producten van ondernemers raken hen direct in de omzet. Ook kan er discussie ontstaan over oorzaak en gevolg van bijvoorbeeld verhoging van recreatiedruk. Het is dan verstandig om verliesgevende transactiekosten tot een minimum te beperken, door harde afspraken te maken en die ook juridisch vast te leggen. Het moet alle actoren dan duidelijk zijn dat dit niet gebeurt uit blijk van wantrouwen, maar als basis voor het kweken van onderling vertrouwen, dat nodig is om elkaars belang te dienen en te versterken.

Een min of meer gesloten regionale economie laat zich uitstekend combineren met een strategie van (externe) zonering (rechtsboven in Tabel 1). In deze variant is het voor investeerders van buiten de regio lastiger om voet aan de grond te krijgen, omdat alle gebiedsactoren van nature op elkaar gericht zijn. In een bufferzone die als een schil om het park ligt, kunnen diensten en producten ontwikkeld worden die gebruikmaken van het park of verkocht worden in het park. Daarbuiten kan het park weer een vestigingsfactor zijn voor op duurzaamheid gerichte bedrijven die op andere manieren (bijvoorbeeld via online branding- en reputatieontwikkeling) bijdragen aan het regionale merk. De sturing van de regionale economie kan hier in belangrijke mate de vorm krijgen van een sociaal contract, een stelsel van informele afspraken om daar waar mogelijk elkaars belang te versterken. Daarvoor is groot draagvlak nodig in de regio, vooral bij burgers. Het bestuur van het natuurpark zelf is primair open en inclusief, waarbij wordt samengewerkt met intermediaire organisaties van de regionale economie, zoals een Kamer van Koophandel of een landbouwcoöperatie. Hoe beter dat middenveld op regionaal vlak ontwikkeld is, hoe groter de synergie tussen behoud van biologische diversiteit en het genereren van economische revenuen als resultaat van gezamenlijke branding. Als een zonering ontbreekt, is er eveneens een gesloten regionale economie mogelijk (rechtsonder in Tabel 1), als het park bewoningskernen omvat. Alle activiteiten die worden ontplooid ten aanzien van beleven, vermarkten en dergelijke moeten gericht zijn op wederzijdse waardecreatie en zijn dan 'inliggend'. Het duurzaam beheer en inrichten van het park is daarmee bijna automatisch een samenlevingsvraagstuk voor de lokale en regionale gemeenschappen. De consequentie voor het besturingsmodel is dat deze (wat?) integraal vormgegeven moet worden. Alle actoren zullen zich als eigenaar van het gebied moeten opstellen om de branding te versterken en synergie te bereiken tussen de economische vitaliteit van het park met inwoners en de natuurkwaliteit ervan. Afhankelijk van de vragen kunnen actoren in wisselende constellaties aan tafel zitten om besluiten te nemen. Dit model vraagt om een sterke autoriteit (in Engeland is de National Park Authority vergelijkbaar met een municipal authority). Zonder deze autoriteit lijkt het bijna onmogelijk om het park te laten functioneren als een regionale community met een regionale economie.

\subsection{Governance en merkontwikkeling}

Na de governance-modellen in de vorige paragraaf besteden we nu aandacht aan de relatie governance en merkontwikkeling. Wanneer een merk wordt opgevat als een label of een beleidscategorie voor de standaard van beschermde gebieden, bijvoorbeeld nationale parken of natuurparken, hebben de meeste landen hiervoor een samenwerkingsorganisatie in het leven geroepen. Naast deze samenwerkingsverbanden hebben de parken daarbij zelf een grote rol om het merk in te vullen en te bewaken: het is immers vaak maatwerk. Toetsing en toezicht houden gebeurt 
op verschillende manieren: via besturen van het park zelf (bijvoorbeeld National Park Authority) of via de bewoners die zelf het park hebben ingesteld (Zwitserland). Vaak is via nationale of regionale regelgeving vastgelegd wie de standaard bewaakt. De IUCN/WCPA heeft hierin soms een adviserende rol.

Wanneer een merk wordt opgevat als een verhaal, een identiteit van een gebied met daaraan een branding- of marketingstrategie gekoppeld om de beleving en de economische inkomsten te vergroten, kan de vraag anders worden beantwoord. Governance is dan nodig om ervoor te zorgen dat een sterke merkontwikkeling kan plaatsvinden zonder dat je onder de minimumeisen van de ecologische standaard (verlies van biodiversiteit) terechtkomt. De versterking van het merk roept dan vaak een dilemma op: elk gebied kan immers gecommercialiseerd worden, totdat dit spanningen gaat opleveren met de eisen van de standaard zoals natuurkwaliteit. Als toerisme en inkomsten leidend zijn, wie bewaakt dan de standaard van natuur? Merkontwikkeling en groei van bezoekersaantallen mogen niet ten koste gaan van de natuur- en landschapskwaliteit. Daarbij is het belangrijk om gebieden te zoneren dan wel afspraken te maken over waar compensatie voor wordt betaald. Daarbij is heel belangrijk of gebieden met zones aangeven wat wel en niet is toegestaan., dan wel steeds onderhandelen waar iets gecompenseerd wordt als iets wordt toegestaan. Belangrijk is dan dat de nieuwe governance-arrangementen voor Nationale Parken nieuwe stijl zowel pr- en marketingpartijen omvat als bewakers van de natuurkwaliteit. Benadrukt daarbij dient te worden dat de laatsten meer gewicht of het laatste woord zouden moeten hebben om te zorgen dat geopereerd wordt binnen de wettelijke kaders van bescherming en binnen de filosofie van de CBD.

\subsection{Thema's en governance-arrangementen}

De discussie over de verschillende governance-modellen kan aangescherpt worden door concreet na te gaan wat er allemaal geregeld moet worden. Uiteraard spelen er zaken rondom basisbescherming, beheer, beheerafstemming, ruimtelijke inrichting, toegankelijkheid en beleving, ruimtelijke ordening, financiering, educatie en wellicht ook deelname aan Europese projecten. Dit zou je kunnen zien als het standaardpakket. Het wordt ingewikkelder als daar een intensieve en goed georganiseerde marketing en branding aan wordt toegevoegd. In Tsjechië heeft de overheid speciaal branding beleid gevoerd voor de parken, waarvan men kan leren als het gaat om welke concrete activiteiten er dan worden ontplooid en hoe die qua governance georganiseerd zijn. Ook is er een actieve community onder de naam @Natura2000branding (leden in Spanje, Italië, Griekenland en Transsylvanië) actief in Europa, die met steun van de Commissie het 'zuur' van de beperkende regelgeving 'verzoet' met economische kansen ${ }^{5}$.

Het beleid in Tsjechië inzake branding ${ }^{6}$ laat zien dat er dan aspecten bijkomen, zoals 1) regionale producten die qua merk refereren aan het park; 2) diensten en services die direct of indirect met het park te maken hebben; 3 ) certificering en labeling alsmede regels voor toepassing van de brand; 4) regionaal organisatorische verbindingen met tradities; 5) binnenhalen van lokale actieve groepen en 6 ) het ontwikkelen van een huisstijl en promotieactiviteiten. Deze extra activiteiten worden in het geval van Tsjechië ontplooid door een regionaal coördinatiecentrum, die daarvoor samenwerkt met een certificeringscommissie, producenten en dienstverleners of hun vertegenwoordigers (zoals de Kamer van Koophandel of een associatie van producenten) en een nationaal coördinator.

Ondernemers betalen een fee om het label te mogen voeren (tussen de $€ 60$ en $€ 200$ ), hetgeen kan worden gezien als een soort lidmaatschap. Uiteraard vindt promotie plaats, bijvoorbeeld door middel van jaarmarkten en presentaties. Gewerkt wordt vanuit het principe "in de regio, voor de regio". Het werken volgens dergelijke simpele principes maakt de brand sterk, maar er zijn tot nog toe te weinig verkoopmogelijkheden en kansen.

\footnotetext{
5 http://www.natura2000branding.eu/

6 http://www.fao.org/fileadmin/user_upload/Europe/documents/Events_2013/4thRD/PPT/Sedmikova_en.pdf http://www.elo.org/UserFiles/File/KAZMIERSKI.pdf?PHPSESSID=9fc4fa80eed1d68068a27d126a400156 http://www.natura.org/sites_cz_krkonose.html
} 
In de voorbeelden zien we dat ondernemers actief bijdragen aan de brand en daar zelf ook beter van worden, maar ook dat een belangrijke tegenprestatie wordt geleverd door de parkorganisatie met een actieve marketing, zoals Natura 2000-gebieden volop gesteund worden door de overheid (de Europese in dit geval, soms ook nationale overheden, zoals in Italië). Ook het Europese LifeScape-project laat zien dat regionale branding voordelen oplevert voor de agrariër en vooral ook de vorming van sociaal kapitaal bevordert, hetgeen vereist is voor het ontstaan van regionale netwerken (Maessen, R. \& L. J ones-Walter, 2008). Deze netwerken maken de omgeving uit van de governance die landschap, park en de lokale gemeenschappen met elkaar verbindt. Deze branding-governance is in belangrijke mate informeel, wederkerig, verbonden met netwerken en vooral ook lerend.

Bij de verschillende economische modellen ontstaan ook verschillen in nadruk op branding of marketing. Branding is bijvoorbeeld meer gericht op producten en diensten uit de regionale economie. Marketing is meer van toepassing op de toeristeneconomie.

\subsection{Differentiatie in ambitie binnen de standaard}

In paragraaf 3.4 zijn vier governance-modellen uitgewerkt, welke zich in meer of mindere mate lenen voor het bereiken van hoge ambities ten aanzien van merkontwikkeling. De mogelijke ambities willen we hier in beeld brengen op een wijze die is geïnspireerd door de analyse van werelderfgoedgebieden van James Rebanks (zie slot hoofdstuk 2). Om de niveaus van Rebanks te duiden en te onderscheiden, is gebruikgemaakt van een internationale verkenning. We combineren daarbij fysieke gegevenheden, wetgeving en publiek private samenwerking. Voor nationale parken wordt aanbevolen om met één standaard te werken. Binnen die standaard zou, evenals James Rebanks heeft aanbevolen voor de werelderfgoedgebieden, met verschillende ambitieniveaus gewerkt kunnen worden. In navolging van Rebanks zou een soortgelijke piramide opgesteld kunnen worden, die de verschillende ambitieniveaus tot uitdrukking brengt.

Primair (eerste laag van Figuur 4) is er de natuur in een natuurpark die beschermd en beheerd wordt, en waar een formele status aan wordt toegekend. Bezoekers komen er om het landschap, dieren en planten te zien en voor rust. Er vindt informatieoverdracht plaats via educatieve programma's. Hier voldoen de meeste Nederlandse nationale parken aan.

Op een hoger ambitieniveau (de tweede laag van Figuur 4) is er het natuurpark waarin landschap, cultuurhistorie en tradities verweven worden, zodat het park een verhaal heeft waar mensen met een algemene interesse en belangstelling op af komen. Het verhaal wordt door recreatieondernemers uitgedragen en het park heeft een actieve marketing strategie. Hier valt te denken aan het voorbeeld van Foutain Abbey, zoals geschetst aan het begin van hoofdstuk 1.

Aan een nog hoger ambitieniveau (de derde laag in Figuur 4) voldoen slechts enkele parken die voldoen aan de beschrijving van laag 2 , en waarin er tevens sprake is van branding van de regionale economie in een wijdere omgeving dan van het park zelf. Lokale producten (landbouw, kunst etc.) dragen de regionale identiteit uit op een wijze die gevonden kan worden in Parco d'Abruzzo (of de Abruzzen). Er zijn afspraken en lidmaatschappen die er voor zorgen dat de brand gebonden is aan regels en die zorgen dat iedereen profiteert en een aandeel krijgt, zoals de situatie in Tsjechië laat zien.

Het hoogste niveau (de vierde laag in Figuur 4) hebben we (nog) niet heel duidelijk gevonden in de internationale verkenning, maar deze zou kunnen bestaan uit een verbijzondering van laag drie, namelijk dat de regionale brand niet bestaat uit een stelsel van afspraken, maar vooral uit een gedeelde strategie ten aanzien van het ontwikkelen van een brand, het inspireren van de regionale economie met deze brand en het beschermen van de kwaliteiten in termen van natuur, landschap, cultuur en cultuurhistorie. Dit is slechts mogelijk als de natuur bij wet afdoende beschermd is, zodat er geen interne tegenstrijdigheden kunnen ontstaan tussen het ontplooien van branding-activiteiten en de bescherming van de biodiversiteit. De strategie is niet enkel gericht op verbetering van de regionale leefbaarheid, maar ook op duurzaam toerisme.

Aldus ontstaat het volgende beeld: 


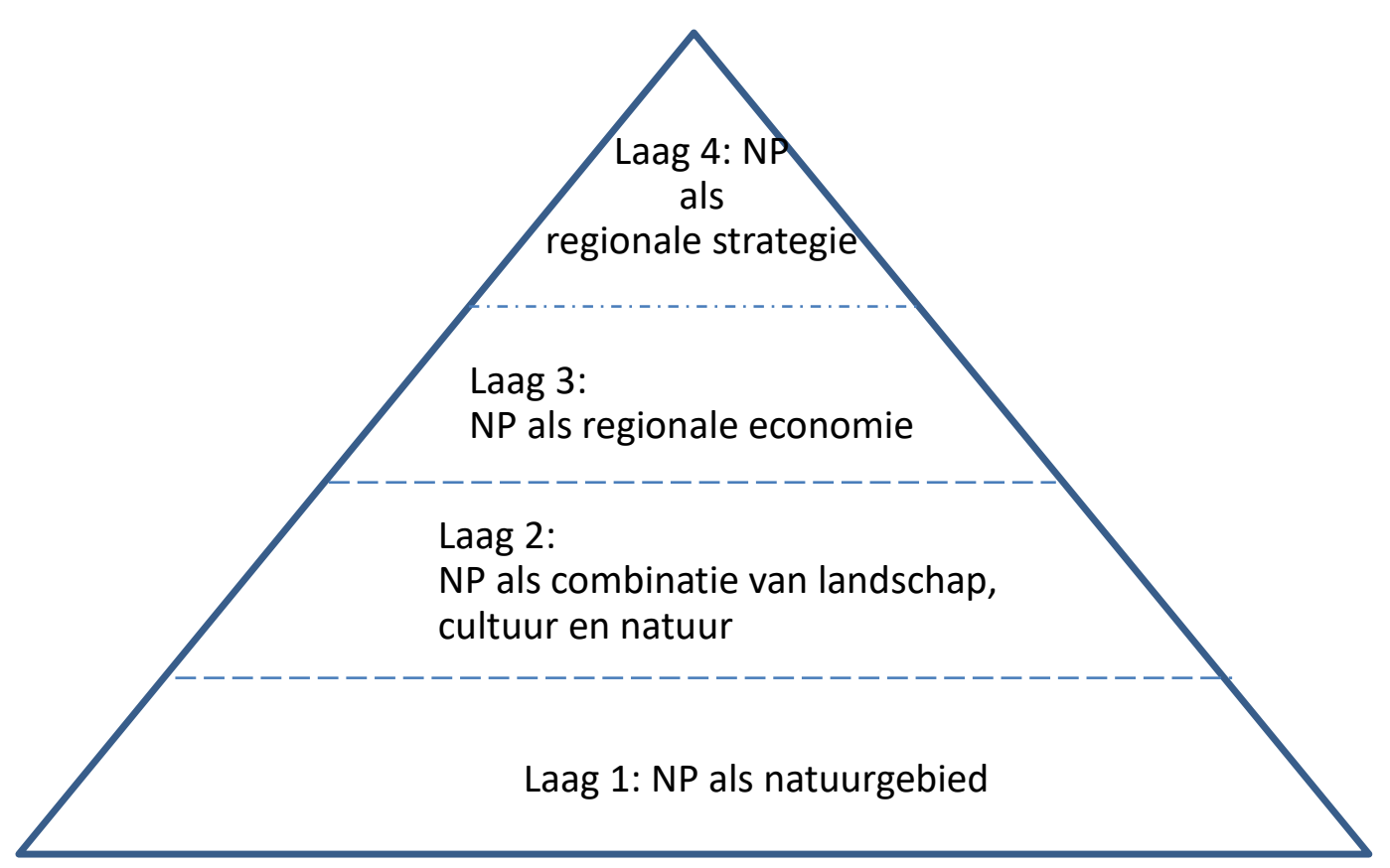

Figuur 4 Rebanks' indeling van ambitieniveaus uit Figuur 2, toegepast op nationale parken.

Hoe meer nationale parken de sociaaleconomische ontwikkeling betrekken, hoe hoger zij in de piramide komen. Overigens maken wij op analytische gronden onderscheid tussen de regionale/lokale economie en de internationale economie, maar wij spreken geen voorkeur uit. Betekenisverlening door nationale parken aan de internationale economie is voor ons dus niet van een hogere orde dan betekenisverlening door nationale parken aan de regionale economie. Wel is het van een andere orde. $\mathrm{Bij}$ een regionale economie gaat het om regionale inbedding en draagvlak, bij de nationale economie gaat het om internationale profilering, grote gebieden, verbonden met grote nationale/internationale partners. Het is van belang om vast te stellen dat meer naar boven in Figuur 4 de governance complexer van aard is. Complexiteit ontstaat hier door een sterke toename van wederzijdse afhankelijkheden tussen een groter aantal actoren. In steeds hogere mate zijn ze op elkaar aangewezen. Hieronder wordt het verschil tussen de bovenste laag en het niveau daaronder uitgewerkt.

Het verschil in governance tussen de derde en (hoogste) vierde laag valt als volgt te bezien (zie Tabel 2).

Tabel 2 Consequenties van een hogere ambitie voor de governance-structuur.

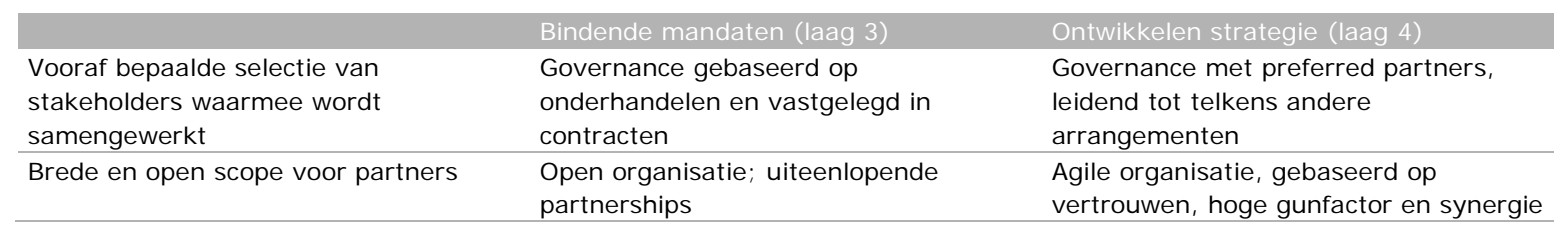

Bij laag 4 staan niet de organisaties en de eigenaren van deelgebieden meer voorop in de nationale parken, maar wordt een 'wij-gevoel' ervaren. Er is sprake van gedeeld eigenaarschap: iedereen voelt zich eigenaar van het park en niet alleen voor het deel met een eigen belang. Bij het bereiken van deze laatste laag doen formele governance-structuren er minder toe. Mensen weten elkaar informeel te vinden, vertrouwen elkaar en gunnen elkaar van alles, omdat er synergie ontstaat. Het bevordert de vorming van sociaal kapitaal (Maessen, R. \& L. J ones-Walter, 2008). Als samenwerking informeel georganiseerd is, zijn er ook weinig transactiekosten. Om laag 4 te bereiken, kan juridische bescherming en financiële ondersteuning vanuit de overheid als een minimumvoorwaarde nodig zijn, opdat private actoren het idee krijgen dat ze er niet alleen voorstaan. 


\subsection{Terugkijkend naar Nederland vanuit de quickscan: wat valt op?}

Ten behoeve van de vergelijking met buitenlandse voorbeelden zijn we nagegaan onder welke gebiedscategorieën de nationale parken in Nederland zijn aangemeld. Over de aanmelding van de nationale parken bestaat namelijk verwarring of de aanmelding nu is gebeurd onder categorie IV (SNP, 2007; Pro Facto, 2009) of onder categorie V (SNP, 2015) van de IUCN. Raadpleging van de World Database on Protected Areas (WDPA) van de IUCN bood ons uitsluitsel, want daar kun je de IUCN categorie voor de nationale parken in Nederland vinden

( https: //www. protectedplanet. net/country/NL): categorie II. Ook zijn de natuurgebieden opgenomen in een Europese lijst, de Common Database on Designated Areas (CDDA). De CDDA wordt beheerd door de European Environment Agency (EEA). De informatie over Nederland (252 natuurgebieden) hiervoor wordt aangeleverd door de overheid. Alle nationale parken zijn in de CDDA aangemeld als IUCN categorie II.

Met het indienen van de bidbooks in Nederland zijn suggesties gedaan voor een andere begrenzing van de nationale parken. Feitelijk is een situatie ontstaan die het Servicenet Landschappen (2016) eerder heeft getypeerd als drie ruimtelijke strategieën ${ }^{7}$ :

a. Nationale parken ingebed in een groter nationaal landschap.

b. Het versterken van de samenhang tussen centrale natuurkernen en ontwikkelingskansen benutten in de cultuur- of stedelijke randen.

c. Opschalen en verbinden van nationale parken: aaneenschakelen van gebieden en attracties.

We kunnen vaststellen dat met de strategie in de bidbooks een aanzet is gemaakt voor de zonering die veel in het buitenland wordt aangetroffen, namelijk van categorie II-gebieden ingebed in categorie IV-gebieden alsmede een nog verdere externe zonering buiten de grenzen van de beschermde gebieden die deel uit kunnen maken van de regionale brand. Overigens wordt binnen de nationale parken al langer met zonering gewerkt. Een opvallend verschil met een aantal landen in het buitenland is echter dat in andere landen bufferzones rond nationale parken worden aangehouden of meer activiteiten in de buitenste randen van de parken mogelijk zijn. Minder harde overgangen of contrasten in de randen zijn daarmee mogelijk. Het is de vraag of een extra categorie $V$ als hulpmiddel voor de externe zonering nuttig zou kunnen zijn in de Nederlandse situatie ${ }^{8}$. Er bestaat een nauwe relatie tussen beheerdoelen en de rolverdeling en het relatieve gewicht van stakeholders binnen de governance van een gebied: in categorie $\mathrm{V}$ kan dan de rol van toerisme en boerensectoren veel sterker zijn.

Het valt op dat veel andere landen een sterke wettelijke verankering van nationale parken kennen, maar ook van Natuurparken (zie Bijlage 3). Die natuurparken waren voorheen vergelijkbaar met onze oude beleidscategorie Nationale landschappen, die overigens door Nederland nooit als IUCN categorie waren aangemeld. Het valt op dat in de Nederlandse regelgeving een stelselvisie en - strategie voor de integrale samenhang van de beschermde gebieden grotendeels ontbreekt ${ }^{9}$. Ook is de financiële bijdrage van het rijk in andere landen vaak wettelijk vastgelegd. Landen als Duitsland en Engeland maken daarnaast gebruik van loterijgeld, wat in Nederland enkel nog incidenteel gebeurt: alleen postcodeloterijgeld bij de Marker Wadden is ingezet, als onderdeel van het te vormen Nationaal Park Nieuwland.

Nederland kent, in tegenstelling tot het buitenland, geen harde planologische of juridische status toe aan nationale parken. Het feit dat het in Nationale Parken veelal om Natura 2000-gebieden gaat waar de VHR van toepassing is, maakt overigens wel dat de nationale parken via deze status toch harde bescherming genieten.

7 Deze strategieën zouden mogelijk een invulling kunnen geven aan doelstelling 1.2 van het werkprogramma van de Conventie Biologische Diversiteit: "To integrate protected areas into broader land- and seascapes and sectors so as to maintain ecological structure and function."

8 Zie hiervoor ook de hoofdstukken 4 en 5 van Dudley et al. (2008: p 36-37 en p 41).

9 Zo heeft Nederland geen National Biodiversity Strategic Action Plan (NBSAP), maar heeft de regering de AICHI doelen van het $C B D$ versleuteld in diverse beleidssporen, waaronder het Natuurpact met de provincies. 
Wat verder opvalt, is dat Nederland de implementatie voor beschermde gebieden vooral zelf vorm lijkt te geven, zonder actieve betrokkenheid of hulp van bijvoorbeeld Europarc of IUCN/WCPA. Landen als Duitsland en Spanje betrekken Europarc en IUCN/WCPA veel meer bij hervormingen van beleid voor beschermde gebieden, of het nu gaat om de categorieën en de ruimtelijke strategie, de governance of de wijze van monitoren en evalueren. Duitsland besteedt veel aandacht aan de governance van het monitoren en evalueren van kwaliteit in beschermde gebieden en haalt hierbij rapportages aan van de WCPA/IUCN en andere internationale studies en heeft dit vervolgens vastgelegd in een eigen document, getiteld 'Qualitätskriterien und standards für Deutsche Nationalparke' en de veelzeggende ondertitel: 'Entwicklung eines Evalueringsverfahres zur überprüfung der managementeffektivität'. Ook voor Natuurparken en Biosfeerreservaten zijn dergelijke instrumenten ontwikkeld. Daarnaast besteedt Duitsland apart aandacht aan de governance van de planning en de governance van het hanteren van labels en merken. Duitsland en Spanje hebben verder ook sterke contacten met Europarc, wat zich vertaalt in eigen organisaties: Europarc Germany en Europarc Spain. Deze landen zoeken dus vooral de internationale governance op bij het implementeren van standaarden en merken. Er bestaat overigens ook een Europarc Low Countries, waar Nederland en België samen deel van uit maken. De samenwerking met Europarc is echter minder sterk dan bijvoorbeeld bij Duitsland of Spanje. Nederland zou zich veel meer kunnen laten inspireren door Europese en Global organisaties als Europarc, IUCN en UNESCO. Andere landen maken daarbij vanuit de betrokken ministeries ook geld vrij om die samenwerking te kunnen aangaan. Opvallend is nu ook dat Nederland in diverse Europese projecten voor beschermde gebieden van natuur ontbreekt, zoals duidelijk wordt uit het onlangs verschenen boek over Natuurparken in Europa (Köster and Denkinger, 2017).

Een ander verschil met het buitenland is de verbinding tussen regionale producten en nationale parken. Omdat in Nederland agrariërs vaak geen deel uitmaken van de nationale parken, wordt er een verbinding gemist om streekproducten nadrukkelijker te koppelen aan nationale parken. Dit is een gemiste kans. De Nationale Parken nieuwe stijl kunnen wel gebieden met agrariërs omvatten en bieden een uitgelezen kans om streekproducten aan nationale parken te verbinden.

Wellicht het belangrijkste verschil met de situatie in de onderzochte landen is de zwakke status van de nationale parken alsmede van het samenwerkingsverband. Bescherming van biodiversiteit gebeurt niet enkel door het toepassen van regels voor milieu- en ruimtegebruik, maar ook door het toekennen van autoriteit en het delegeren van zeggenschap aan de nationale parkorganisaties. De combinatie van veel stakeholders rond de parken, een nog niet uitgekristalliseerde biodiversiteitsstrategie en een zwakke positie in het openbaar bestuur van de nationale parken leidt tot veel wrijvingsverliezen en transactiekosten. Dit is een twijfelachtige uitgangspositie voor het toekennen van een actieve rol aan nationale park-organisaties om voor een regio een gebiedsbranding op poten te zetten. Als we deze organisaties daar goed voor klaar willen zetten is, zoals de voorbeelden in I talië, Duitsland en Engeland laten zien, er een regionaal bestuur nodig dat vergelijkbaar is met een WGR++ regio, waar nationale parken zich in de kern van bevinden, geflankeerd door andere regionaal opererende economische, toeristische en landbouwkundige organisaties. Gebiedsbranding krijgt niet zijn beslag met goede voornemens en overleg, maar daar is ook uitvoeringsmacht voor nodig. Wellicht is dit nu allemaal te vroeg en stuit het op weerstanden van de nationale parken. Mogelijk zijn nationale parken hier meer voor in als zij verschillende ontwikkelstadia hebben doorgemaakt en tegen de randen van de maakbaarheid vanuit de eigen parken blijven aanlopen. 


\section{$4 \quad$ Conclusies}

Hieronder worden de conclusies gegeven van deze quickscan. Deze zijn geformuleerd aan de hand van drie vragen:

1) Welke inspirerende governance praktijken zijn gevonden bij de quickscan governance in het buitenland?

2) Hoe kijken we vanuit deze quickscan opnieuw naar de Nederlandse situatie?

3) Welke lessen zijn te trekken en adviezen te geven?

\section{Welke inspirerende governance praktijken zijn gevonden bij de quickscan governance in het buitenland?}

Allereerst moet gezegd worden dat het ultieme inspirerende buitenlandse voorbeeld niet bestaat. Overal wordt gezocht naar een goed werkende biodiversiteitsstrategie en worden acties ondernomen om door middel van branding en marketing de positie van verschillende soorten natuurparken te versterken. In deze quickscan is gekeken naar governance-arrangementen die kunnen leiden tot synergie tussen behoud en herstel van biodiversiteit met een sociaaleconomische impulswerking die van een nationaal park kan uitgaan, gebaseerd op onder meer branding en marketing.

In het buitenland is een stelsel van gebieden dat bescherming geniet niet alleen gericht op nationale parken, maar ook op regionale natuurparken, vergelijkbaar met de gebieden die wij in Nederland voorheen nationale landschappen noemden. In veel van de onderzochte landen vormt zonering een belangrijk instrument in de governance van parken. Dat kan gaan om interne zonering, binnen de begrenzing van een park, maar ook om externe zonering. In een aantal gevallen wordt zo'n zonering gekoppeld aan een specifieke IUCN categorie, bijvoorbeeld Categorie V.

In de onderzochte landen is er steevast sprake van gehele of gedeeltelijke overheidsfinanciering. Dit is vooral van belang om een 'parkorganisatie' te bemensen die verantwoordelijk is voor het opzetten van nieuwe verbindingssporen richting de markt en de gemeenschap. Het gaat dan om merkontwikkeling en -bewaking, educatie, organiseren marketing, communicatie, coördineren van projecten, die netwerken opzet/samenwerkingen regelt, die het beheer van de natuur in het gebied coördineert etc.). En als aanjaagbudget voor projecten (trigger money). Uit deze quickscan komt verder naar voren dat richting de markt en gemeenschap op twee manieren verbindingen worden versterkt: via de regionale economie of via een model van return of cash flows, waarbij bedrijven nationale parken bijvoorbeeld sponsoren uit overwegingen van reputatiemanagement of via massatoerisme geld wordt verdiend.

In de combinatie van wel of geen zonering met een economisch model van return of cash flows (een soort baatbelasting) of regionale economie, liggen vier verschillende governance-modellen besloten (zie eerder gepresenteerd Figuur 4). Ze verschillen in integraliteit ingeval er wel of geen zonering is en ook in het vormgeven en onderhouden van financiële arrangementen. Alle vier de modellen zijn relevant en begaanbaar voor de nationale parken in Nederland. Soms ontstaan samenwerkingen min of meer vanzelf om een natuurpark tot middelpunt van een regionale brand te maken, zoals in I talië en Engeland. Soms stuurt de overheid op branding en marketing, zoals in het geval van Tsjechië. Als het min of meer vanzelf gaat, werkt het minder verplichtend en lijkt het enthousiasme groter. Op vele plaatsen wordt geëxperimenteerd in het kader van Europese projecten.

Binnen het kader van de vier governance-modellen kunnen de ambities in hoge mate uiteenlopen. Dit geld zowel voor natuurparken als voor werelderfgoedgebieden. In deze quickscan zijn daarbij vier lagen onderscheiden, analoog aan de analyse van 200 werelderfgoed-locaties van James Rebanks (zie eerder gepresenteerd Figuur 2). De basale laag bestaat uit behoud van biodiversiteit en educatie- en belevingsactiviteiten. Daarboven speelt de ambitie van een optimale wisselwerking tussen cultuur, cultuurhistorie, landschap en natuur. De één na hoogste ambitie kan worden gevonden in een nationaal park dat functioneert als brandpunt van een regionaal sociaaleconomisch systeem. De 
hoogste ambitie kan bestaan uit een nationaal park als regionale strategie met een minimum aan transactiekosten en een maximale synergie tussen behoud en herstel van ecologische kwaliteiten en economisch functioneren (zie eerder gepresenteerd Figuur 5).

\section{Hoe kijken we vanuit deze quickscan opnieuw naar de Nederlandse situatie?}

In Nederland zijn de nationale parken gericht op een harde natuurkern en worden alleen recreatieve belevingsactiviteiten om deze kern heen toegestaan. De planologische scheiding tussen parken en de omgeving is vrij scherp: er zijn geen geleidelijke overgangszones. Daardoor mist de aansluiting met de omgeving. In andere landen is er veel meer sprake van zonering, waarbij ook een schil wordt betrokken waar economische activiteiten plaatsvinden, bijvoorbeeld van agrariërs.

Opvallend is dat het Nederlandse beleid slechts gebrui maakt van twee IUCN-categorieën. De buitenlandse voorbeelden laten zien dat een combinatie van meerdere categorieën behulpzaam kan zijn bij het vinden van een goed werkend governance-arrangement in een situatie die uit meerdere zoneringen bestaat. Tevens laten die voorbeelden zien dat regionale branding gebaat is bij een goede infrastructuur waarin organisaties inzake landbouw, toerisme, duurzaam ondernemen en andere goed kunnen samenwerken. Dat gebeurt veelal via organen waar intermediaire organisaties in zitten. De analyse heeft laten zien dat de Nederlandse nationale parken geen optimale aansluiting hebben bij hetgeen er aan initiatieven en projecten loopt in Europa. Dit kan mogelijk samenhangen met het volgende punt: een gebrek aan (juridische en bestuurlijke) status en een gebrek aan middelen en menskracht.

Ondanks het feit dat de natuur in Nederland een vergelijkbare bescherming geniet met de parken in landen om ons heen, is de positie van de nationale parken in hun regisserende rol beduidend zwakker en dat werkt ook door in het beschermen van de biodiversiteit. De financiering van nationale parken zijn na 2013 in Nederland niet meer bij wet geregeld en vastgesteld. Ook dit maakt het lastig om voluit in Europese programma's en projecten mee te gaan.

\section{Welke lessen zijn te trekken en adviezen te geven?}

Voor de uitwerking van de governance is uitgegaan van differentiatie in ruimtelijke strategieën en in economische keuzes. Voor de te ontwikkelen standaard Nationale Parken nieuwe stijl betekent de verschillende ruimtelijke strategieën en verschillende economische modellen kunnen worden gevolgd, waarbij verschillende vormen van governance horen. Afhankelijk van het ambitieniveau dat wordt nagestreefd, kan hier meer of minder op worden ingezet. Die ambitieniveaus kunnen verschillen binnen een en dezelfde standaard. Hoe hoger het ambitieniveau, hoe complexer de governance wordt. Tegen deze achtergrond worden de volgende aanbevelingen gegeven. Deze zijn erop gericht om de parken afzonderlijk en het samenwerkingsverband adequaat in stelling te brengen om hun coördinerende rol en taken uit te breiden naar de sociaaleconomische omgeving en desgewenst naar de internationale toeristenindustrie.

Om de standaard verder uit te werken, wordt aanbevolen inspiratie te halen uit de Green List van de IUCN, het Biodiversiteitsverdrag, de UNESCO-criteria en de sociale en economische impact ervaringen van James Rebanks bij werelderfgoedgebieden. Ook wordt aanbevolen om hierbij meer contact te onderhouden met Europarcs en IUCN. Het ministerie van LNV kan hiertoe het SNP en/of het nieuwe programmabureau bij Staatsbosbeheer financieren om hier capaciteit voor vrij te maken.

Versterk status en financiering vanuit het rijk voor de nieuwe rol die nationale parken gaan oppakken in het proces van regionale branding en of internationale marketing. Daarnaast wordt aangeraden om de rechtspositie en ook de bestuurlijke positie zo aan te passen dat elk van de parken zelfstandig kan meedoen in Europese programma's en projecten. Op die manier kan optimaal geleerd worden van ontwikkelingen en experimenten elders.

Het lijkt ons van belang dat parken aangeven waar ze hun energie op willen zetten: op een proces van regionale branding en een regionale economie of op de marketingbenadering van return of cash flows dan wel baatbelasting van ondernemers die voordeel ondervinden van de aanwezigheid van het park. Hier ligt een duidelijke taak voor de provincie, namelijk in het vormen van het intermediair veld dat bij kan dragen aan branding. Dat kan ver gaan als de provincie bereid is om de ruimtelijk economische programmering af te stemmen op het verhaal van de regio. 
Een belangrijke les uit het buitenland is de belangrijke rol die verschillende soorten van zoneringen kan spelen. Het verdient aanbeveling om voor de Nederlandse situatie te onderzoeken in hoeverre een externe zonering een basis kan bieden voor gebiedsbranding.

De laatste en belangrijkste aanbeveling is om de governance niet in te richten op het behalen van targets, maar in te richten op experimenteren en leren. Dat kan door middel van het werken met tijdelijke structuren, die op een lerende wijze geëvalueerd worden en bijgesteld kunnen worden naar bevind van zaken. 


\section{Literatuur}

Borrini-Feyerabend, G., N. Dudley, T. Jaeger, B. Lassen, N. Pathak Broome, A. Phillips and T. Sandwith (2013). Governance of Protected Areas: From understanding to action. Best Practice Protected Area Guidelines Series No. 20, Gland, Switzerland: IUCN.

Borrini-Feyerabend, G., P. Bueno, T. Hay-Edie, B. Lang, A. Rastogi and T. Sandwith (2014). A primer on governance for protected and conserved areas, Stream on Enhancing Diversity and Quality of Governance, 2014 IUCN World Parks Congress. Gland, Switzerland: IUCN.

Commissie Realisatie Natuurverkiezing, 2017. Wanneer een Nationaal Park?

Dudley, N., 2008. Guidelines for Applying Protected Area Management Categories, IUCN, Gland (Switzerland), 2008.

Hallmann CA, Sorg M, J ongejans E, Siepel H, Hofland N, Schwan H, et al. (2017) More than 75 percent decline over 27 years in total flying insect biomass in protected areas. PLOS ONE 12(10): e0185809. doi.org/10.1371/journal.pone.0185809

IUCN, 2003a. Governance Stream at the Vth World Parks Congress, World Parks Congress V, Durban,.

IUCN, 2003b.Emerging Issues: Workshop Stream III: Governance of protected areas - New Ways of Working Together, Annex 1: Private Protected Area Action Plan, IUCN World Parks Congress V, 2003b.

IUCN and World Commission on Protected Areas (WCPA) (2016a). IUCN Green List of Protected and Conserved Areas: Standard, Version 1.0. Gland, Switzerland: IUCN.

IUCN and World Commission on Protected Areas (WCPA) (2016b). IUCN Green List of Protected and Conserved Areas: User Manual, Version 1.0. Gland, Switzerland: IUCN.

Kamerbeek, H, 2015. Ondernemen met natuur. Tips voor grondeigenaren. Utrecht: Stichting Matrijs.

Köster, U and K. Denkinger (eds) with the collaboration of J. Liesen (VDN), K. Risthaus (VDN) and C. Ritchie (EUROPARC Federation), 2017. Living Landscapes. Europe`s Nature, Regional, and Landscape Parks - model regions for the sustainable development of rural areas.

Lake District World Heritage Project, 2009. World Heritage Status. Is there opportunity for economic gain? A preview of unique research commissioned by the Lake District World Heritage Project into the economic impacts of World Heritage Status around the world. Cumbria, Lake District World Heritage Project and Northwest. Regional Development Agency.

Lausche, B., 2011. Guidelines for Protected Area Legislation, IUCN, Gland (Switzerland).

Maessen, R. \& L. Jones-Walter, 2008. Branding our landscapes: some practical experiences from the LIFESCAPE project. Conference Paper, 8th European IFSA Symposium, 6 - 10 July 2008, Clermont-Ferrand (France). WS 4: Landscape as a frame for and a product of development in rural areas.

Ministerie van EZ (Economische Zaken), 2004. Convention on Biological Diversity. Fifth National Report of the Kingdom of the Netherlands. Den Haag, Ministerie van Economische Zaken.

Ministerie van IenM (Infrastructuur en Milieu), 2012. Structuurvisie Infrastructuur en Ruimte (SVIR). Nederland concurrerend, bereikbaar, leefbaar en veilig. Den Haag.

Ostermann, O., 2013. Protected Areas Governance in Germany. Presentation at Europe Nordic Baltic Section. Seminar on Protected Areas Governance, April 3-4 2013 Suure-Jaani, Estonia.

Pedroli, B. \& A. van Doorn, G. de Blust, M.L. Paracchini, D. Wasscher, F. Bunce (eds.), 2007. Europe's Living Landscapes. Essays exploring our identity in the countryside. Landscape Europe, Wageningen/KNNV, Zeist.

PNP (Programmabureau Nationale Parken van Wereldklasse), 2016. Programmaplan Transitie 'Naar Nationale Parken van Wereldklasse' 2015-2018.

Rebanks, J., 2012. The potential for a new fundraising model for World Heritage Destinations.

SNP(Samenwerkingsverband Nationale Parken), 2007. Ontstaansgeschiedenis, feiten en ontwikkelingen Nederlandse Nationale Parken 1975-2006. Den Haag.

SNP (Samenwerkingsverband Nationale Parken), 2011. Waardevolle natuur verdient eigen geld. Werving van private inkomsten door nationale parken.

SNP (Samenwerkingsverband Nationale Parken), 2015. 
Staatscourant d.d. 2 mei 2016, nr 2280. Reglement voor de verkiezing 'Mooiste natuurgebied van Nederland', behorend bij het Programma 'Naar Nationale Parken van Wereldklasse. Tweede Kamer, 30 oktober 2014.

Motie Van Veldhoven/Jacobi over nationale parken nieuwe stijl - 34000 XIII Vaststelling van de begrotingsstaten van het Ministerie van Economische Zaken (XIII) en het Diergezondheidsfonds (F) voor het jaar 2015, Nr. 76 MOTIE VAN DE LEDEN VAN VELDHOVEN EN JACOBI.

\section{Websites:}

https: //www.iucn.org/theme/ protected-areas/our-work/iucn-green-list

UK

http://www. nationalparks.gov.uk/students/wholooksafternationalparks/costsandspending

http://www. bbc.com/news/uk-38462686

US

https://smartasset.com/taxes/the-economics-of-national-parks

http://www.ti.org/npsprobs1.html

http://www. hoover.org/research/make-our-national-parks-self-sufficient

https: //headwaterseconomics. org/public-lands/protected-lands/economic-impact-of-national-parks/

EU

http://www.europarc.org/

Germany

http://www. european-parks. org/who-we-are/ verband-deutscher-naturparke

Italië

http://www. parks. it/indice/ Efaq. aree. protette. html 


\section{Bijlage 1 De standaard van de IUCN van beschermde gebieden}

I -a Strikt natuurreservaat. Strikt beschermd voor biodiversiteit en mogelijk ook geologische/geomorfologische eigenschappen, waar menselijk bezoek, gebruik en impact gecontroleerd en gelimiteerd worden om de bescherming van natuurwaarden te verzekeren.

I-b Wildernisgebied. Meestal grote, onaangetaste of licht gemodificeerde gebieden, hun natuurlijke karakter en invloed behoudend, zonder permanente of significante menselijke bewoning, beschermd en beheerd om hun natuurlijke conditie te behouden.

I I Nationaal park. Grote natuurlijke of semi-natuurlijke gebieden aangewezen om grootschalige ecologische processen en karakteristiek voor het gebied zijnde soorten en ecosysteem eigenschappen te beschermen, welke aanvullend een fundering bieden voor milieu en cultureel verenigbare spirituele, wetenschappelijke, educatieve, ontspannende en bezoekmogelijkheden.

I I I Natuurlijk monument of kenmerk. Gebieden die een specifiek natuurlijk monument beschermen, zoals een landvorm, onderzeese berg, zeegrot of geologische kenmerk, maar ook een levend kenmerk zoals een oud bos.

IV Habitat/ soorten beheer gebied. Gebieden om specifieke soorten of habitats te beschermen, waar het beheer deze prioriteit weerspiegelt. Vaak zullen regelmatige, actieve ingrepen nodig zijn om aan de behoeften van specifieke soorten of habitats te voldoen, maar dit is geen vereiste voor de categorie.

V Beschermd landschap of zeeschap. Gebieden waar de interactie tussen mens en natuur door de tijd een eigen karakter heeft vervaardigd, met significante ecologische, biologische, culturele en landschappelijke waarden en waar waarborging van de integriteit van deze interactie essentieel is voor de bescherming en duurzaamheid van het gebied en geassocieerde natuurconservatie en andere waarden.

VI Beschermde gebieden met een duurzaam gebruik van natuurlijke hulpbronnen. Gebieden die ecosystemen in stand houden, samen met geassocieerde culturele waarden en traditionele natuurlijke bron-beheersystemen. Meestal grote, voornamelijk in een natuurlijke conditie verkerende gebieden, met een deel onder duurzaam natuurlijk bron-beheer en waar gering niet-industrieel natuurlijk brongebruik passend bij natuurbehoud plaatsvindt als een van de hoofddoelen. 


\section{Bijlage 2 De standaard voor good governance van de IUCN}

\footnotetext{
Principles

Legitimacy

and voice

Direction

Performance

Considerations related to the principles

- Establishing and maintaining governance institutions that enjoy broad acceptance and appreciation in society

- Ensuring that all rightsholders and stakeholders concerned receive appropriate and sufficient information, can be represented and can have a say in ackising and/or making decisions

- Fostering the active engagement of social actors in support of protected areas, upholding diversity and genderequity

- Extending special support to vulnerable groups, such as indigenous peoples, women and youth, and preventing discrimination on the basis of ethnicity, gender, social class, financial assets, etc.

- Maintaining an active dialogue and seeking consensus on solutions that meet, at least in part, the concems and interest of everyone

- Promoting mutual respect among al rightsholders and stakeholders

- Honouring agreed rules, which are respected because they are "owned" by the people and are not only because of fear of repression and punishment

- As much as possible attributing management authority and responsibility to the capable institutions closest to natura resources (subsidiarity)

- Developing and following an inspiring and consistent strategic vision (broad, long-term perspective) for the protected areas and their conservation objectives, grounded on agreed values and an appreciation of the ecological. historical, social and cultural complexities unique to each context

- Ensuring that governance and management practice for protected areas are consistent with the agreed values

- Ensuring that governance and management practice for protected areas are compatible and well-coordinated with the plans and policies of other levels and sectors in the broader landscape/seascape and respectful of national and international obligations (including CBD PoWPA)

- Providing clear policy directions for the main issues of concern for the protected area and, in particular, for contentious issues (e.g., conservation pribrities, relationships with commercial interests and extractive industries) and ensuring that those are consistent with both budgetary allocations and management practice

- Evaluating and guiding progress on the basis of regular monitoring results and a conscious adaptive management approach

- Favouring the emergence of champions, generating new ideas and carefully allowing/promoting the testing of innovations, including governance and management innovations for protected areas

- Achieving conservation and other objectives as planned and monitored, including through on-going evaluation of management effectiveness

- Promoting a learning culture for protected area poilcy and governance practice on the basis of mechanisms, tools and partnership that promote on-going collaborative learning and cross-fertilzation of experience

- Engaging in advocacy and outreach for the benefit of protected areas

- Being responsive to the needs of rightsholders and stakeholders, including by providing timely and effective response to inquiries and reasonable demands for changes in governance and management practice

- Ensuring that protected areas staff, and rightsholders and stakeholders, as appropriate, have the capacities necessary to assume their management roles and responsibilities and that those capacities are used effectively

- Making an efficient use of financial resouroes and promoting financial sustainability

- Promoting social sustainability and resilience, i.e., the ability to manage risks, overcome the inevitable crises and emerge strengthened from the experience

- Uphoiding the integrity and commitment of all in charge of specific responsibilities for the protected areas

- Ensuring transparency, with rightsholders and stakeholders heving timely access to information about: what is at stake in decision-making; which processes and institutions can exert influence; who is responsible for what; and how these people can be made accountable

- Ensuring a clear and appropriate sharing of roles for the protected areas, as well as ines of responsibility and reporting/answerability

- Ensuing that the financial and human resources allocated to manage the protected areas are properly targeted according to stated objectives and plans

- Evaluating the performance of the protected area, of its decision makers and of ins staft, and linking quality of results with concrete and appropriate rewards and sanctions

- Establishing communication avenues (e.g., web sites) where protected area performance records and reports are accessible

- Encourage performance feed-back from chil society groups and the media

- Ensure that one or more independent public institution (e.g., ombudsperson, human rights commission, auditing agency) has the authority and capacity to oversee and question the action of the protected areas governing bodies and staff
} 


\begin{tabular}{|c|c|}
\hline Principles & Considerations related to the principles \\
\hline $\begin{array}{l}\text { Fairness } \\
\text { and rights }\end{array}$ & $\begin{array}{l}\text { - Striving towards an equitable sharing of the costs and benefits of estabishing and managing protected areas and } \\
\text { fairness in taking all relevant decisions } \\
\text { - Making sure that the livelihoods of vulnerable people are not adversely affected by the protected areas; that } \\
\text { protected areas do not create or aggravate poverty and socially-disruptive migratory patterns; and that the costs of } \\
\text { protected areas - especially when born by vulnerable people-do not go without appropriate compensation } \\
\text { - Making sure that conservation is undertaken with decency and dignity. without humiliating or haming people } \\
\text { - Dealing fairly with protected area staff and ternporary employees } \\
\text { - Enforcing laws and regulations in impartial ways, consistently through time, without discrimination and with a right to } \\
\text { appeal (rule of law) } \\
\text { - Taking concrete steps to respect substantive rights (legal or customary, collective or individual) over land, } \\
\text { water and natural resources related to protected areas, and to redress past violations of such rights } \\
\text { - Taking concrete steps to respect procedural rights on protected area issues, including: appropriate information } \\
\text { and consultation of rightsholders and stakeholders; fair conflict management practices; and non-discriminatory } \\
\text { recourse to justice } \\
\text { - Respecting human rights, including individual and colective rights, and gender equity } \\
\text { - Respecting the rights of indigenous peoples, as described in the UN Declaration of the Pights of Indigenous } \\
\text { Pecples? } \\
\text { - Ensuring strictly the free, prior and informed consent of indigenous peoples for any proposed resettlement related } \\
\text { to protected areas } \\
\text { - Promoting the active engagement of rightsholders and stakeholders in establishing and governing protected areas }\end{array}$ \\
\hline
\end{tabular}




\section{t Bijlage 3}

In deze Bijlage worden gegevens over de standaard en de governance per land gepresenteerd. Het onderzoek betrof een quickscan waarvoor een gering aantal onderzoeksdagen beschikbaar was. De onderzoekers zijn zich dan ook bewust dat zij geen volledig beeld per land kunnen schetsen. Verder waren de onderzoekers erg afhankelijk van ongelijksoortige beschikbare gegevens voor een document- en websiteanalyse. Dit leidt ertoe dat de landen hieronder niet allemaal op vergelijkbare wijze beschreven kunnen worden.

\begin{tabular}{|c|c|c|c|c|}
\hline $\begin{array}{l}\text { Europese } \\
\text { landen }\end{array}$ & $\begin{array}{l}\text { Aantal nationale parken en/ of regionale } \\
\text { natuurparken }\end{array}$ & Organisatie nationaal park & Eigendom en beheer van het park & $\begin{array}{l}\text { J uridische inbedding en eventuele bevoegdheid ruimtelijke } \\
\text { ordening }\end{array}$ \\
\hline Duitsland & $\begin{array}{l}16 \text { nationale parken en } 104 \text { regionale } \\
\text { natuurparken }\end{array}$ & $\begin{array}{l}\text { Het bestuur van een } \\
\mathrm{NP} \text { bestaat uit } \\
\text { vertegenwoordigers } \\
\text { vanuit de } \\
\text { natuurbescherming, } \\
\text { gemeenten, } \\
\text { Landesregierung, } \\
\text { Kamer van } \\
\text { Koophandel, landbouw, } \\
\text { promotie recreatie en } \\
\text { toerisme, waterschap, } \\
\text { buitensportsector en } \\
\text { wetenschap }\end{array}$ & $\begin{array}{l}\text { Meer dan } 90 \% \text { van het Nationaal } \\
\text { Parkgebied is publiek eigendom }\end{array}$ & $\begin{array}{l}\text { Duitsland heeft een Federale natuur- en landbeschermingswet } \\
\text { (Gesetz über Naturschutz und Landschaftspflege } \\
\text { (Bundesnaturschutzgesetz - BNatSchG). Het Duitse } \\
\text { federalisme is hervormd in 2006: de Federale } \\
\text { Natuurbeschermingswet was een raamwerk- ofwel kaderwet } \\
\text { en is sinds } 2006 \text { een 'concurrerende wet' (Ostermann, 2013). } \\
\\
\text { De RO bevoegdheid is beperkt, met name gericht op } \\
\text { toegankelijkheid en zonering van gebruik } \\
\text { (toerisme, jacht, visserij etc.) }\end{array}$ \\
\hline Frankrijk & $\begin{array}{l}10 \text { nationale parken, waarvan } 3 \text { overzee en } \\
51 \text { regionale natuurparken. }\end{array}$ & & $\begin{array}{l}\text { Nationale parken worden } \\
\text { uitsluitend beheerd door } \\
\text { overheidsinstanties onder het } \\
\text { gezag van het Ministerie van } \\
\text { Milieu. }\end{array}$ & $\begin{array}{l}\text { In Frankrijk is de wet op de nationale parken ondertekend op } \\
14 \text { april } 2006 \text { (die de wet op de oprichting van nationale } \\
\text { parken van } 1960 \text { gedeeltelijk wijzigt). De wet verklaart dat } \\
\text { een grondgebied kan worden ingesteld tot Nationaal Park } \\
\text { "wanneer er bijzondere belangstelling is voor het behoud van } \\
\text { zijn natuurlijke milieu en zijn fauna, flora, bodem, } \\
\text { ondergrond, water, atmosfeer en - eventueel - cultureel } \\
\text { erfgoed. Daarom is het belangrijk om een dergelijk milieu te } \\
\text { beschermen tegen verslechtering en tegen elke interventie } \\
\text { die de diversiteit, aspect, samenstelling en evolutie ervan kan } \\
\text { veranderen". }\end{array}$ \\
\hline
\end{tabular}




\begin{tabular}{|c|c|c|c|c|}
\hline $\begin{array}{l}\text { Europese } \\
\text { landen }\end{array}$ & $\begin{array}{l}\text { Aantal nationale parken en/of regionale } \\
\text { natuurparken }\end{array}$ & Organisatie nationaal park & Eigendom en beheer van het park & $\begin{array}{l}\text { J uridische inbedding en eventuele bevoegdheid ruimtelijke } \\
\text { ordening }\end{array}$ \\
\hline Italië & $\begin{array}{l}24 \text { nationale Parken en } 152 \text { regionale } \\
\text { natuurparken }\end{array}$ & & $\begin{array}{l}\text { Het grootste deel van het land in } \\
\text { beschermde gebieden is particulier } \\
\text { eigendom. }\end{array}$ & $\begin{array}{l}\text { De wettelijke situatie om de beschermde gebieden te } \\
\text { managen, is de raamwerkwet voor beschermde gebieden, no. } \\
394 \text {, die dateert van } 6 \text { december 1991, welke de } \\
\text { fundamentele principes voor de institutie en het management } \\
\text { van beschermde gebieden benadrukt en hun missie bekijkt, } \\
\text { de classificering weergeeft en bijbehorende governance. Het } \\
\text { zet ook de regelgeving uit voor nationale en regionale } \\
\text { beschermde gebieden. }\end{array}$ \\
\hline Spanje & $\begin{array}{l}15 \text { nationale parken en } 149 \text { regionale } \\
\text { natuurparken }\end{array}$ & $\begin{array}{l}\text { Nationaal Park bestuur } \\
\text { bestaande uit } \\
\text { vertegenwoordigers } \\
\text { van Rijk, provincie, } \\
\text { gemeente en } \\
\text { stakeholders vanuit } \\
\text { recreatie, landbouw, } \\
\text { bosbouw, omringende } \\
\text { eigenaren }\end{array}$ & Publiek eigendom & $\begin{array}{l}\text { Nationale parken worden opgericht door de centrale overheid } \\
\text { op voorstel van de relevante autonome regio, die vervolgens } \\
\text { verantwoordelijk is voor het beheer. } \\
\text { leder NP heeft een technische staf die verantwoordelijk is } \\
\text { voor beheer en ruimtelijke } \\
\text { ordening binnen het NP. }\end{array}$ \\
\hline Engeland, Wales & $\begin{array}{l}10 \text { Nationale Parken in Engeland en } 3 \\
\text { Nationale Parken in Wales } \\
33 \text { AONBs in Engeland en } 4 \text { AONBs in Wales }\end{array}$ & $\begin{array}{l}\text { National Park Authority } \\
\text { bestaande uit } \\
\text { vertegenwoordigers } \\
\text { van de diverse } \\
\text { bestuurslagen (State, } \\
\text { District-, Borough- en } \\
\text { Parish concil) }\end{array}$ & $\begin{array}{l}\text { Grotendeels privaat, } \\
\text { beperkt } \\
\text { overheidseigendom }\end{array}$ & $\begin{array}{l}\text { National Park and Countryside Act 1948, in } 2000 \text { "update" } \\
\text { door middle van de CROW act (Countryside and Rights } \\
\text { of Way Act 2000). } \\
\text { Het NP heeft een zelfstandige RO bevoegdheid } \\
\text { binnen de begrenzing van het park. }\end{array}$ \\
\hline Zweden & $\begin{array}{l}29 \text { Nationale Parken en } 3500 \\
\text { Natuurreservaten }\end{array}$ & $\begin{array}{l}\text { Beheerd door de staat, } \\
\text { maar is gedelegeerd aan } \\
\text { provincies. }\end{array}$ & Rijksoverheid & $\begin{array}{l}\text { Volgens de Zweedse wet moeten de nationale parken } \\
\text { representatieve biotopen zijn die in hun natuurlijke staat of in } \\
\text { wezen onveranderd zijn, maar ook mooie omgevingen die } \\
\text { door de bezoekers kunnen worden ervaren. } \\
\text { RO bevoegdheid ligt bij Swedish National Environmental } \\
\text { Protection Agency). }\end{array}$ \\
\hline
\end{tabular}


Zwitserland

1 nationaal park en 18 natuurparken

In Zwitserland zijn natuur- en landschapsbescherming in de

In Zwitserland zijn natuur- en landschapsbescher
federale grondwet vastgelegd en kantons zijn

verantwoordelijk voor de afdwinging van wetten. De

gedeeltelijke herziening van de federale wet inzake de

bescherming van natuur en cultureel erfgoed (NCHA) en de

verordening inzake parken van nationaal belang (Parks

Ordinance, PO) is een brede nationale en regionale inzet om

Ordinance, $\mathrm{PO}$ ) is een brede nationale en regiona

de ontwikkeling van parken in Zwitserland te
vergemakkelijken en te ondersteunen. De federale

vergemakkelijken en te ondersteunen. De federale
autoriteiten erkennen alleen parken die zijn gebaseerd op

regionale initiatieven en steun genieten van de lokale

gemeenschap. 
Duitsland

Nationale parken worden beschermd door een wettelijk statuut of verordening op het federale staat niveau en ruimtelijk ordeningssysteem (Europarc Germany, 2013). Natuurparken (die momenteel voornamelijk afhankelijk zijn van de aanwijzing als landschappelijke gebieden) zijn relatief slecht beschermd tegen grondgebruiksverandering

in vergelijking met de nationale parken

Het Duits beleid erkent beschermde gebieden als een van de belangrijkste instrumenten voor

biodiversiteitsbescherming op het platteland dat bijna geheel door het menselijk gebruik wordt gedomineerd, maar erkent ook dat effectief behoud van biodiversiteit maatregelen vereist om druk te beperken in het breder landschap (BfN, 2010a; BMU, 2007 in

Underwood et al. 2014)). De Duitse

biodiversiteitsstrategie (BMU, 2007) bevat een doel plus bijbehorende acties om het beschermde netw

versterken, en in het bijzonder zijn ecologische

connectiviteit, die overeenkomt met de Duitse implementatie van CBD doel 11 .

Onderstaande tekst is gebaseerd op

Underwood et al. (2014). De biodiversiteitsdoelstellingen

van de nationale parken en natuurreservaten worden

individueel per gebied gedefinieerd in een wettelijk

statuut en een gedetailleerd gebiedsmanagement plan

( $v$ gl. met beheer- en inrichtingsplan). Ook wordt

verwacht dat plannen een structuur bieden voor

biodiversiteitsbehoud en gebiedsgebruiksdoelen. Het

Duitse natuurbeschermingsagentschap geeft

aanbevelingen hoe synergie kan worden bereikt tussen

enerzijds biodiversiteitsbehoud en anderzijds levering

van ecosysteemdiensten in beschermde gebieden, zoals:

\section{Eevernance}

Een aantal van de nationale parken heeft gebruiksvrijstellingen in hun geschreven beheerplannen die in strijd zijn met de procesbeschermingsdoelstelling (Europarc Germany, 2013). Nationale parkautoriteiten hebben soms problemen met het onderhandelen over duurzaam gebruik met andere overheden op regionaal en lokaal niveau, bijvoorbeeld met betrekking tot jacht, vissen en waterkracht.

Recreatie wordt beschouwd als een van de belangrijkste activiteiten in de Duitse

beschermde gebieden, maar recreatiebeheer

wordt gezien als een lagere prioriteit door de Duitse parkbeheerders, voornamelijk door het gebrek aan middelen (Von

Ruschkowski et al. 2013). De Duitse nationale parken ontvangen meer dan 50 miljoen

bezoekers per jaar, met een totale waarde van ongeveer 2,1 miljard Euro per jaar (Job, 2010).
Bij wet door de betreffende

'Landesregierung'. De

'betreffende gemeenten

hebben een doorslaggevende stem bij het wel of niet aanwijzen. 

voor de drinkwaterkwaliteit zijn met het primaire doel van het behoud en rivieren en hun vloedvlaktes $m$

herstel van natuurlijke processen, zijn er toch ecosysteemdiensten te herstellen

habitatkenmerken op landbouwgrond behouden om de biologische bestrijding van ongedierte te behouden en ziekten te voorkomen

innovatieve financiële instrumenten ontwikkelen die betalingen voor ecosysteemdiensten implementeren herstel wetlands en omzetten van akkerbouw naar permanent grasland en de uitstoot van broeikasgassen uit kassen verminderen

het gebied van bossen te vergroten en de intensiteit van het bosgebruik

energiebesparende investeringen en het gebruik van hernieuwbare energie op gebouwen en boerderijen stimuleren en de bevolking binnen en rond beschermde gebieden over klimaatverlagingsmaatregelen informeren

een systematisch en continu sociaaleconomisch

controlesysteem implementeren voor alle grootschalige beschermde gebieden

financiering voor plattelandsontwikkelingsmaatregelen in en rond beschermde gebieden bevorderen en verhogen de opleiding voor duurzaamheid in alle beschermde

gebieden systematisch bevorderen, inclusief 
Nationale parken worden gevormd door een of meer

centrale zones en perifere gebieden. In het 'hart'/de ker worden sommige menselijke activiteiten gereguleerd om verandering in de fauna, flora, natuurlijke omgeving en landschap te voorkomen.

\section{Regionale natuurparken}

Het doel van regionale natuurparken is het beschermen, beheren en ontwikkelen van kleinere gebieden,

gekenmerkt door een rijk natuurlijk en cultureel erfgoed, maar waarvan het kwetsbaar evenwicht wordt bedreigd. Het grondgebied van een regionaal park valt samen met die van de gemeenten die aan het bijbehorende handvest voldoen, een document waarin de doelstellingen van het park en de acties worden aangegeven om te realiseren. De beheerautoriteiten van regionale parken worden gevormd door

vertegenwoordigers van alle belanghebbende entiteiten regio's, departementen en gemeenten. Regionale parken richten zich op:

het erfgoed van het grondgebied beschermen door een geschikt beheer van natuurlijke omgevingen en landschappen;

bijdragen aan de planning van het grondgebied; verbetering van de economische, sociale en

culturele ontwikkeling, evenals de kwaliteit van leven

het verstrekken van passende wensen, educatie

en informatie aan bezoekers;

relevante experimentele acties uitvoeren en

bijdragen aan onderzoeksprojecten.
Frankrijk heeft geleidelijk de richtlijnen van

internationale verdragen en Europese wetgeving

geïntegreerd in een bredere visie op

landplanning met een koppeling van

milieubescherming en economische

ontwikkeling. Na afloop van het Rio-verdrag van

1992 en de oprichting van het Natura 2000-

netwerk van de Europese Unie heeft het een

grootschalig beleid ontwikkeld voor contractueel

beheer van biodiversiteit, waardoor de

betrokkenheid van de lokale belanghebbenden

wordt vergroot. Het decentralisatieproces in de

jaren tachtig heeft bijgedragen tot deze

ontwikkeling: de wet inzake lokale democratie

(2002) zorgt voor een nauwere betrokkenheid

van de lokale overheden bij het beheer van

beschermde gebieden en geeft regionale

overheden de mogelijkheid om

natuurreservaten te creëren. Die ontwikkeling is

versterkt door de wet van 14 april 2006,

waardoor de overheden een grotere rol spelen
De oprichting van een beschermd gebied kan

De oprichting van een beschermd gebied kan

of via een openbaar onderzoek om het publiek te informeren en zijn standpunten over het

voorstel te verkrijgen. Dit geldt voor de

ontwikkeling van nationale parken en voor het

regionaal charteren voor natuurparken. 
Italië houdt er verschillende niveaus van bescherming op na (Wet 394/91) voor natuurgebieden:

Nationale parken: bestaande uit land-, rivier-, meer- en mariene gebieden die een of meer ecosystemen bevatten die intact worden gehouden of slechts beperkt worden belast door menselijke tussenkomst. Het gaat om

fysieke, geologische, geomorfologische of biologische karakteristieken met een internationaal of nationaal belang. Daarbij kan worden gedacht aan natuurlijke, wetenschappelijke, esthetische, culturele, educatieve en recreatieve kenmerken, waarbij interventie van de staat is vereist om deze te behouden voor huidige en toekomstige generaties.

Regionale en interregionale natuurparken: bestaande uit land-, rivier-, meer- en soms kustgebieden, met een grote natuur- en milieuwaarde, die een enkel systeem

vormen dat de grenzen tussen twee of meer bestuurlijke regio's kan overschrijden; de waarde ervan kan afkomstig zijn van de natuurlijke activa van het gebied van de schoonheid van het landschap en/of van de artistieke en culturele tradities van de bewoners.

\section{Spanje}

De wet 5/2007 definieert nationale parken als "natuurlijke ruimtes met een hoge ecologische en culturele betekenis en die weinig beïnvloed zijn door menselijke activiteiten. Het behoud van hun bijzondere ecologische, esthetische, culturele, educatieve en wetenschappelijke waarden verdient bijzondere aandach en wordt beschouwd als een algemeen belang van de staat." Samen met een nationaal park wordt een 'perifere beschermingszone' opgericht die grenst aan het grondgebied van het park om zijn waarden over te brengen naar de omliggende gebieden en de ecologische impact van buitenaf op het grondgebied van het park te verminderen

(http://www. parks.it/world/ES/Epage_menu.php?id=12)
Governance

Nationale parken en mariene gebieden komen

onder het vaandel van het Italiaanse Ministerie

van Milieu en de Bescherming van Land en Zee,

terwijl regionale parken worden beheerd door

de verschillende regionale overheden. Zodra

een park in Italië is opgericht, dient het door

een onafhankelijke instelling, als een aparte

rechtspersoon, beheerd te worden

Beschermde gebieden worden gefinancierd door

publieke bronnen die worden beheerd door

nationale en regionale overheden. Veel parken hebben zelf-financierende mechanismen, doo het aanbieden van toeristische voorzieningen,

milieueducatie en de verkoop van ambachtelijke producten etc.
Specifieke beheerplannen met specifieke doelen zijn een sleutelsteen van het beschermd ruimtesysteem. Netwerken als concept van beschermd gebiedsbeheer is snel ontwikkeld tijdens de laatste paar jaren. Het systeem word meestal gecoördineerd door te beginnen met werken, om ervoor te zorgen dat lokale

prioriteiten worden aangepakt en geintegreerd met bredere sociale aspiraties.

Deelnemingsraden ('Patronatos' en 'J untas Rectoras') spelen op dit punt een belangrijke rol. Ondanks deze recente vooruitgang

vertrouwen beschermde gebieden in Spanje nog steeds op beperkte budgetten en onvoldoende human resources (De Lucio, J. \& C. Martínez Alandi, 2008).
Instellingsproces van gebieden

Een nationaal park of natuurreservaat kan slechts worden aangewezen als het beheerplan is goedgekeurd. In dit plan worden de doelstellingen en de maatregelen voor het behoud van het gebieden gedefinieerd. De wet bepaalt dat doelstellingen en maatregelen verder gaan dan de grenzen van het beschermd gebied, om doelstellingen voor de ecologische verbinding van het gebied vast te stellen, hoewel dit niet altijd in de praktijk wordt gedaan (Europarc España, 2012a). 
Nationale parken zijn plattelandsgebieden waarin dorpen zijn gelegen, en beschermd worden vanwege hun

prachtige platteland, de natuur en het cultureel erfgoed. Mensen wonen en werken in de nationale parken en de boerderijen, dorpen en steden zijn beschermd samen

met het landschap en het wild. National parken

verwelkomen bezoekers en bieden kansen voor iedereen om te ervaren, te genieten en te leren over hun

bijzondere kwaliteiten. Elk nationaal park wordt verzorgd door een organisatie genaamd National Park Authority. Deze komen sterk overeen met de doelstellingen van de nationale parken in Engeland en Wales:

1) Het behouden en vergroten van de natuur en het cultureel erfgoed van het gebied.

2) Het promoten van duurzaam gebruik van de natuurlijke bronnen van het gebied.

3) Het promoten van begrip en beleving (inclusie beleving in de vorm van recreatie) van de speciale kwaliteiten van het gebied bij het publiek.

4) Het promoten van duurzame economische en sociale ontwikkeling van de in het gebied levende

gemeenschappen.

Interessant is dat de nationale parken de plicht hebben om te streven naar economisch en sociaal welzijn van de lokale gemeenschappen binnen hun grenzen.

Gebieden van buitengewone natuurlijke schoonheid (Areas of Outstanding Natural Beauty) omvatten complete landschappen, inclusief steden en dorpen. $Z$ hebben dezelfde rechtsbescherming voor hun landschappen als nationale parken, maar hebben geen eigen autoriteiten voor planningscontrole en andere diensten zoals nationale parken hebben. In plaats daarvan worden ze gecontroleerd door partnerschappen tussen lokale gemeenschappen en lokale overheden.
Ruwweg gesteld wordt ruim $50 \%$ van de

bestuursleden van ieder nationaal park geleverd

door de autoriteiten in de regio. De overige zijn

aangesteld door de staatssecretaris van

Milieubeheer, Voedselvoorziening en

Plattelandszaken. Maar, ieder park heeft het

weer op zijn eigen manier geregeld.

Tegenwoordig wordt het bestuur rechtstreeks

betaald door de staat. Vroeger was er een soort

verdeelsleutel waarbij een gedeelte door de

regio en een gedeelte door de staat betaald

werd. (http://reizen-en-

recreatie.infonu. nl/europa/99227-nationale-

parken-van-engeland-en-wales.html)

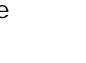


Zweden heeft onverkort de richtlijnen van de IUCN Protected Areas Categories geadopteerd en zet daarbi
op het aanwijzen van gebieden die voldoen aan de op het aanwijzen van gebieden die voldoen aan de
criteria van Categorie II. Als beginsel daarbij geldt het gebied groot genoeg moet zijn om een of meer complete ecosystemen te bevatten die niet significant gewijzigd zijn door menselijke arbeid of exploitatie. Verder moeten nationale parken aan de volgende voorwaarden voldoen (Löfgren (2008) in De Voorwaarden vol al. 2016)

Een algemeen of uniek type Zweeds landschap representeren, individueel en als een nationaal breed systeem.

Complete landschapssecties bedekken van niet minder dan 1.000 hectare.

In de eerste plaats bestaan uit ongerepte natuurlijke landschappen.

Prachtig of karakteristiek zijn en daarmee een interessante bestemming voor bezoekers.

Een hoge natuurbeschermingswaarde hebben.

In staat zijn om effectief beschermd te worden en

tegelijkertijd ook gebruikt te worden voor onderzoek.

recreatie en toerisme zonder dat schade aan hun

natuurlijke waarde plaatsvindt.
Naturvårdsverket, het Zweedse

Milieubeschermingsagentschap, is het centrale overheidsinstituut dat verantwoordelijk is voo de uitvoering van het

natuurbeschermingsbeleid, met inbegrip van voorstellen voor de oprichting van nieuwe parken (de beslissing om een park in te stellen wordt door het Zweedse parlement gem terwijl de lokale overheden de leiding hebben over het management van nationale parken. De Zweedse overheid is de

eerstverantwoordelijke voor de nationale parken in Zweden en de grond is eigendom van de

$Z$ weedse overheid. Dat wil niet zeggen dat

Zweden vanuit top-down governance of

government de nationale parken aanstuurt. $\mathrm{Er}$ is

een groeiend besef dat top-down governance

van nationale parken in Zweden kan leiden tot

verlies van lokaal draagvlak. Met de

consequentie dat behouddoelstellingen voor

natuur niet worden gerealiseerd, heeft geleid tot

het ontwikkelen van alternatieve en meer

inclusieve benaderingen en op hun grondgebied.

Traditioneel natuurbehoud staat nu meer open

voor lokale betrokkenheid waarbij ook

internationale overeenkomsten van de

Conventie van Biodiversiteit wordt aangehaald. 
Om te worden toebedeeld met het park-etiket en

financiële steun te ontvangen, moet aan fundamentele

criteria worden voldaan: hoge natuur- en

landschapswaarden en minimale beperking door

infrastructuur of grondgebruik, samen met

democratische legitimatie. Daarnaast moeten ruimtelijke

ordening en financiering op de lange termijn worden verzekerd en moet er een parkmanagementstructuur zijn. In het kader van de erkenningsfase ontvangen parken op aanvraag het voorlopige kandidaatlabel (parken in oprichting). Er zijn drie categorieën parken van nationaal belang, ontworpen voor verschillende behoeften en toepassingen:

Een nationaal park is een uitgebreid gebied, verdeeld in een kern en een bufferzone. In het kerngebied zijn er strenge beperkingen voor productiebedrijven en menselijke activiteiten, om habitats voor inheemse flora en fauna bescherming te bieden en mogelijkheden voor de natuur en het landschap te bieden om zich verder spontaan te ontwikkelen. De bufferzone is een gebied waar de lokale bevolking woont en werkt. Een nationaal park biedt ook recreatie- en milieueducatie aan het publiek, evenals wetenschappelijk onderzoek.

Een regionaal natuurpark is een uitgebreid, gedeeltelijk natuurlijke waarden en landschapswaarden. Het

bevordert duurzame ontwikkeling, behoud, onderhoud en verbetering van het natuurlijke en culturele erfgoed en van een harmonieus landelijk gebied met landschaptypische nederzetting.

Een natuur-ontdekkingspark is een gebied in een dichtbevolkte regio, met intacte ruimtes voor lokale flora en fauna en verbetering van de leefkwaliteit van de stedelijke bevolking. Het is verdeeld in twee zones: in de kernzone is toegang voor het publiek gereguleerd; het overgangsgebied is ontworpen voor het behoud en verbetering van natuur- en landschapswaarden, en stelt het publiek in staat om de natuur te ervaren en om milieueducatie te ontvangen.
De EUROPARC-conferentie 2016 reflecteerde

door middel van plenaire lezingen en

participerende workshops op het them governance'. Veel aandacht was er voor het specifieke karakter van het model van Zwitse parken: de bottom-up ervaring, die uniek is in de wereld, waarin de bevolking zelf nationale parken instelt. Ze definiëren en ondersteunen duurzame ontwikkelingsprojecten die

ondersteund worden door de verschillende partners, ze zorgen voor uitwisseling, flexibe beheer en resultaten ter bevordering van de hele regio. Er is daarmee aandacht voor:

- Cultuur en traditie: de identiteit van de parken;

Raamwerk condities: betrekken van

overheden bij de regio

- Lokale betrokkenheid: leven in de parken.

Gemeenschappen en belanghebbenden

formuleren hun doelen in het Park Handvest en werken samen aan de uitvoering ervan. Zo wordt de identiteit van de regio versterkt. De Zwitserse nationale parken organiseren een verscheidenheid aan socio-culturele activiteiten, zoals dorpentours, festivals, het uitschrijven van wedstrijden, kooklessen, concertreeksen

Onderwijs en bevorderen van bewustzijn voor duurzame ontwikkeling is een kerntaak van de parken. De parken bieden daar naast een gevarieerd programma van tentoonstellingen, excursies, avondlezingen, discussies en projectweken over verschillende onderwerpen. Hier moeten het bewustzijn en begrip van de natuur, de samenleving en de economie en de complexe interactie worden gestimuleerd en gedemonstreerd met praktische voorbeelden in de gebieden.
Nationale parken worden ingesteld op basis van de inzet van de lokale bevolking. Met hun deeën werken de mensen mee aan de toekomst van de regio. Tot slot bepalen zij zelf of ze dee willen uitmaken van een nationaal park of niet. Deze grassroots-aanpak is uniek in de wereld. Een park brengt zijn inwoners bij elkaar. 


\section{Referenties bijlage}

\section{Duitsland}

\section{Documenten}

Bundesministerium der J ustiz und für Verbrachersschutz, 2017. Gesetz über Naturschutz und Landschaftspflege (Bundesnaturschutzgesetz - BNatSchG) § 27 Naturparke/; zie: http://www.gesetzeim-internet.de/bnatschg_2009/

Bundesministerium der J ustiz und für Verbrachersschutz, 2017.Gesetz über Naturschutz und Landschaftspflege (Bundesnaturschutzgesetz - BNatSchG)§ 26 Landschaftsschutzgebiete; zie: http://www.gesetze-im-internet.de/bnatschg_2009/

Ostermann, O., 2013. Protected Areas Governance in Germany. Presentation at Europe Nordic Baltic Section. Seminar on Protected Areas Governance, April 3-4 2013 Suure-Jaani, Estonia.

Underwood, E., R. Ashcorft, M. Kettunen, A. Mc Conville and G. Tucker, 2014. Protected area approaches in the EU. London/Brussels: Institute for European Environmental Policy.

Vries, D. de, Schaminée, J.H.J., Schipper, P.C., Tersteeg, J.L., 2016. Natuur- en landschapscriteria voor Nationale Parken van Wereldklasse - Naar Nederlandse natuur van internationale allure. Wageningen: Wing Process Consultancy.

Websites

http:// www.gesetze-im-internet.de/bnatschg_2009/

https: //www. naturparke.de/

\section{Frankrijk}

\section{Document}

IUCN France (2013), Protected Areas in France: a diversity of tools for the conservation of biodiversity. Paris: IUCN France.

\section{Websites:}

http:// www. parks.it/ europa/Eindex.html

http:// www.ecologique-solidaire.gouv.fr/

http:// www. parcsnationaux. fr/fr

http://www. parcs-naturels- regionaux.fr/

http:// www. reserves-naturelles.org/

\section{I talië}

Websites

http://www. parks. it/indice/Efaq. aree. protette.html 


\section{Spanje}

\section{Documenten}

De Castro, M. \& V. Urios, 2016. A Management Model for Improve the Governance of Protected Areas since an Institutional Perspective and an Empirical Case in a Spanish Natural Park. In: International J ournal of Engineering Technology, Management and Applied Sciences, September 2016, Volume4, Issue 9, pp. 35-43.

De Lucio, J. \& C. Martínez Alandi, 2008. Connectivity and the Spanish network of Protected Areas EUROPARC-España. 2008. Anuario EUROPARC-España del estado de los espacios naturales protegidos 2007. Ed. Fundación Fernando González Bernáldez. Madrid.

Harrison, P. \& Marina Garcia-Llorente, 2012. Management plans for the Andalusia national parks; Spain. Zie: http://www. besafe-project. net/page. php?P=72\&SP=73

IUCN, 2010. Enhancing the contribution of Protected Areas to Biodiversity Conservation. The role of the CBD Programme of Work on Protected Areas (POWPA) Tenth Meeting of the Conference of the Parties to the Convention on Biological Diversity (CBD COP10), 18-29 October, 2010, Nagoya, Japan. IUCN and UNEP-WCMC, 2011. The World Database on Protected Areas (WDPA): January 2011. Cambridge, UK: UNEP-WCMC.

Underwood, E., R. Ashcorft, M. Kettunen, A. Mc Conville and G. Tucker, 2014. Protected area approaches in the EU. London/Brussels: Institute for European Environmental Policy.

Websites

http://www.parks.it/world/ES/Epage_menu.php?id=12

http://www. mapama.gob.es/es/

http://www. mapama.gob.es/es/red-parques-nacionales/

\section{United Kingdom}

DocumentenUnderwood, E., R. Ashcorft, M. Kettunen, A. Mc Conville and G. Tucker, 2014. Protected area approaches in the EU. London/Brussels: Institute for European Environmental Policy.

Vries, D. de, Schaminée, J.H.J., Schipper, P.C., Tersteeg, J.L., 2016. Natuur- en landschapscriteria voor Nationale Parken van Wereldklasse - Naar Nederlandse natuur van internationale allure. Wageningen: Wing Process Consultancy.

Websites

http://www. parks.it/ world/UK/Eindex.php

http://www. nationalparks.gov.uk/index

https://www.gov.uk/government/organisations/natural-england

http://www.snh.gov.uk/

https: //www.doeni.gov.uk/

http://reizen-en-recreatie.infonu. nl/europa/99227-nationale-parken-van-engeland-en-wales. html

\section{Zweden}

\section{Documenten}

Holmgren, L, C. Sandström and A. Zachrisson, 2017. Protected area governance in Sweden: new modes of governance or business as usual? In: Local Environment. 22: 1. P 22-37.

http: / / www.tandfonline. com/doi/ full/10.1080/13549839.2016.1154518?scroll=top\&needAccess=true Vries, D. de, Schaminée, J.H.J., Schipper, P.C., Tersteeg, J.L., 2016. Natuur- en landschapscriteria voor Nationale Parken van Wereldklasse - Naar Nederlandse natuur van internationale allure. Wageningen: Wing Process Consultancy.

Websites

http://www. parks. it/ world/SE/Epage_menu.php?id=2 


\section{Zwitserland}

\section{Documenten}

Parc J ura vaudois, Swiss Parks Network and EUROPARC Federation, 2016. We are Parks! 18th - 22nd October 2016.

Websites

https://cmsdata.iucn.org/downloads/8_pierre_galland___swiss_protected_areas.pdf https://www.parks.swiss/de/die_schweizer_paerke/taetigkeits_und_wirkungsfelder/gesellschaft_bildu ng.php

https: //www. bafu.admin.ch/naturschutz/index.html?lang=en

https://www. parks.swiss/de/

https: //www. bafu.admin.ch/bafu/en/home/topics/landscape.html?_organization=811\&_topic=29\&_sta rtDate $=01.01 .2016 \&$ _pagel ndex $=0$

https: //www. bafu.admin. ch/bafu/en/home.html?_organization=811\&_topic=29 
Wageningen Environmental Research Postbus 47

6700 AA Wageningen

T 0317480700

www.wur.nl/environmental-research

Wageningen Environmental Research Rapport 2851

ISSN 1566-7197
De missie van Wageningen University \& Research is 'To explore the potential of nature to improve the quality of life'. Binnen Wageningen University \& Research bundelen Wageningen University en gespecialiseerde onderzoeksinstituten van Stichting Wageningen Research hun krachten om bij te dragen aan de oplossing van belangrijke vragen in het domein van gezonde voeding en leefomgeving. Met ongeveer 30 vestigingen, 5.000 medewerkers en 10.000 studenten behoort Wageningen University \& Research wereldwijd tot de aansprekende kennisinstellingen binnen haar domein. De integrale benadering van de vraagstukken en de samenwerking tussen verschillende disciplines vormen het hart van de unieke Wageningen aanpak. 



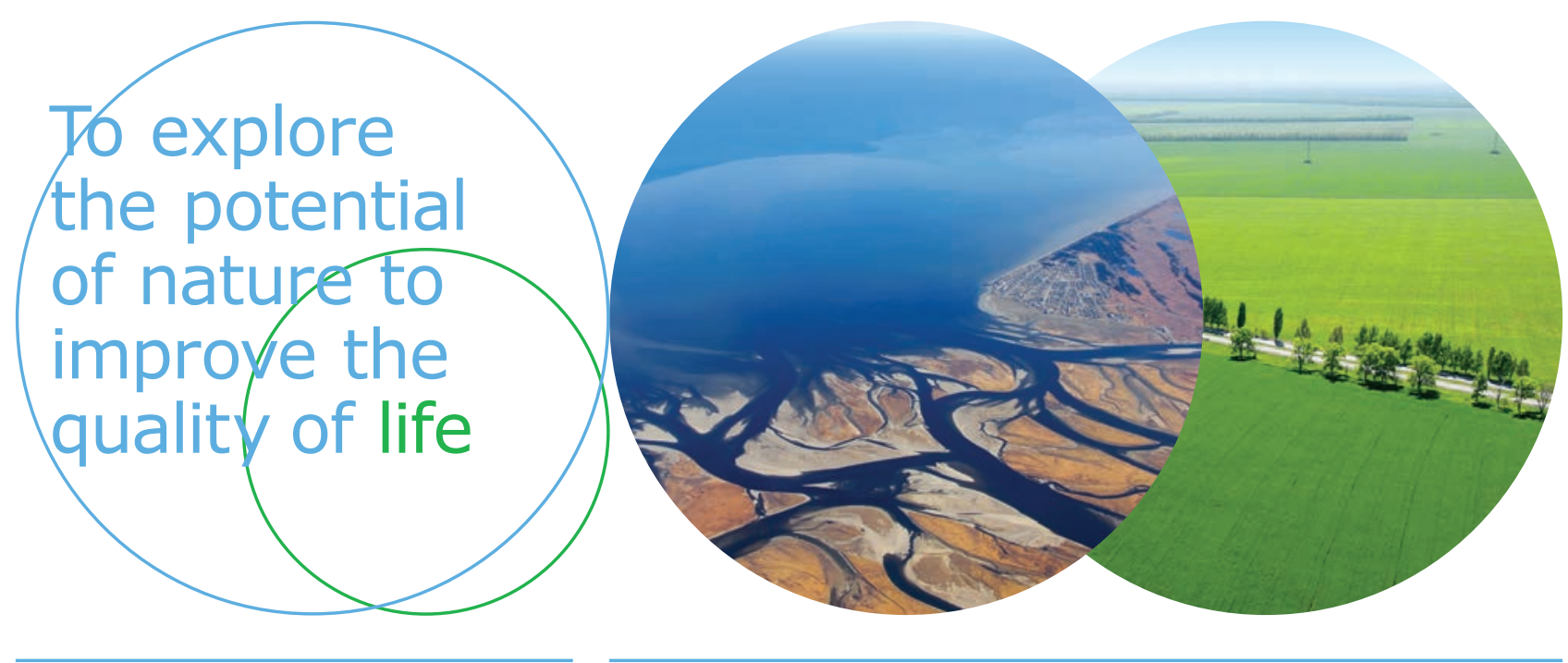

Wageningen Environmental Research Postbus 47

$6700 \mathrm{AB}$ Wageningen

T 317480700

www.wur.nl/environmental-research

Rapport 2851

ISSN 1566-7197
De missie van Wageningen University \& Research is 'To explore the potential of nature to improve the quality of life'. Binnen Wageningen University \& Research bundelen Wageningen University en gespecialiseerde onderzoeksinstituten van Stichting Wageningen Research hun krachten om bij te dragen aan de oplossing van belangrijke vragen in het domein van gezonde voeding en leefomgeving. Met ongeveer 30 vestigingen, 5.000 medewerkers en 10.000 studenten behoort Wageningen University \& Research wereldwijd tot de aansprekende kennisinstellingen binnen haar domein. De integrale benadering van de vraagstukken en de samenwerking tussen verschillende disciplines vormen het hart van de unieke Wageningen aanpak. 